\title{
IMPRESSION MANAGEMENT AND ORGANIZATIONAL AUDIENCES: THE FIAT GROUP CASE
}

\author{
Saverio Bozzolan \\ Department of Economics and Management \\ University of Padova \\ Via del Santo, 33 \\ 35123 Padova, Italy \\ E-mail: saverio.bozzolan@unipd.it \\ Charles H. Cho \\ ESSEC Business School \\ Avenue Bernard Hirsch \\ BP 50105 \\ 95021 Cergy Pontoise Cedex, France \\ E-mail: cho@essec.edu \\ Giovanna Michelon* \\ Department of Economics and Management \\ University of Padova \\ Via del Santo, 33 \\ 35123 Padova, Italy \\ E-mail: giovanna.michelon@unipd.it
}

\section{Acknowledgments:}

We appreciate the helpful comments provided by Qiang Guo, Davide Raggi and participants of the $9^{\text {th }}$ Workshop on Empirical Research in Financial Accounting (Gran Canaria), the $74^{\text {th }}$ Annual Congress 2012 German Academic Association for Business Research (VHB) (Bozen) and the research seminar at the University of Padova. We also thank Elisa Scarparo for her excellent research assistance. Saverio Bozzolan and Giovanna Michelon gratefully acknowledge financial support received from the Italian Ministry of Research (MIUR) under project \#PRIN2007: "Disclosure Quality, Financial Analyst Forecasts and Investment Strategies.”

* Corresponding author 


\title{
IMPRESSION MANAGEMENT AND ORGANIZATIONAL AUDIENCES: THE FIAT GROUP CASE
}

\begin{abstract}
In this paper we investigate whether, and how, corporate management strategically uses disclosure to manage the perceptions of different organizational audiences. In particular, we examine the interactions between the FIAT Group and three of its key organizational audiences - the local press, the international press and the financial analysts, which are characterized by different levels of salience for the company. We focus on both how management reacts to the optimism level existing within each audience and how the narrative disclosure tone adopted by FIAT influences the ex-post optimism in the local and international press or in the financial analyst community. We investigate the disclosure of the FIAT Group over a six-year period (2004-2009), during which 70 price-sensitive press releases were published. On the basis of 1,887 (331) news articles published in Italian (international) newspapers and 411 analyst reports, we report evidence of different strategic patterns in the interaction processes between FIAT and its audiences. Our findings also indicate some differences in the way FIAT is affected by, and in turn, affects the sentiment of each audience, thus highlighting that the salience of the stakeholder is an important driver of the adoption of impression management techniques. Taken together, our findings point to issues related to setting the "tone at the top" and potential ethical matters.
\end{abstract}

Keywords: impression management; optimism; organizational audiences; press releases; salience; narrative disclosure tone 


\section{IMPRESSION MANAGEMENT AND ORGANIZATIONAL AUDIENCES: THE FIAT GROUP CASE}

\section{INTRODUCTION}

In recent years an increasing number of U.S.-based studies on corporate disclosure tone have been conducted. These studies have been primarily investigating whether disclosure tone represents any incremental information for financial market participants (e.g., Davis et al., 2012; Price et al., 2012). Most of these studies examine the associations between disclosure tone, managerial incentives and/or market effects, and share the same methodology — that is, the analysis of a large number of documents using computer software (e.g., Feldman et al., 2010; Baginski et al., 2011). This recent interest, however, neglects a relatively large part of the previous literature that focuses on disclosure as part of a strategy to manage the impression of market participants about the firm (see Merkl-Davies and Brennan, 2007 for an extensive review of the impression management literature). This paper stems from the social psychology perspective of impression management (see Merkl-Davies and Brennan, 2011 for recent insights and updates on this literature) and looks at managerial impression management through narrative disclosures during the interaction process with different organizational audiences.

Despite the potential contribution of cross sectional studies in describing and explaining the determinants and effects of impression management, there has been little research investigating how management interacts with different organizational audiences in terms of corporate disclosure - in other words, how does management react to the existing (and subsequently responsive) sentiment of its different types of audiences? According to Yin (2009), a case study methodology is the preferred research approach to investigate the "how" question. Hence, in this paper, we carry out a longitudinal exploratory case study in order to examine how management strategically utilizes disclosure to manage the impressions 
of the organization's different audiences. Specifically, we examine the interaction processes of a large Italian corporation with three organizational audiences - the local press, the international press and the financial analysts. We selected these three audiences because they are characterized by different levels of salience for the company (Mitchell et al., 1997). We focus on both how management reacts to the (existing) optimism of each audience and how the disclosure tone adopted by the company subsequently is associated with the optimism levels in the local and international press and/or in the financial analyst community.

Our selected company for this study is a large Italian automobile manufacturer, the FIAT Group (hereafter, FIAT), based in Turin. FIAT is an ideal case company to examine these relationships for several reasons. First, FIAT is the largest Italian non-financial company in terms of market capitalization in the Milan stock exchange. Previous literature (for a review, see Merkl-Davies and Brennan, 2007) suggests that impression management tends to be more pronounced in highly visible firms. FIAT is also one of the most important players in the automotive industry — the world's ninth largest carmaker and the largest in Italy. It plays a fundamental role in the Italian economy as it represents a significant percentage of the country's GDP and has been gaining much importance and visibility at the international level following the acquisition of Chrysler, making it a major player in today's global automotive industry. These characteristics provide motivational grounds to analyze the relationship between FIAT and three of its most important financial audiences - the local press, the international press and the financial analysts.

Our investigation focuses on how FIAT's corporate communications appear to be related to the average optimistic tone diffused across the three audiences (hereafter referred to as the "sentiment" of the audience). By focusing on both the local and international press, we capture how FIAT manages its relationships with these audiences in two different situations: (1) when the firm is a major player in the financial markets and in the economic system of a 
country with a high level of interest and under scrutiny from the social and financial community; and (2) when the firm is a "regular" player in the financial markets at the global scale. The same organization is therefore considered a significant entity in its base country and a relatively less visible one worldwide. In addition, we analyze whether management is likely to engage in impression management and how it may seek to influence the press and financial analysts differently. Hence, this particular case study enables us to investigate the interactive process (Ginzel et al., 2004) between the local and international press and the financial analyst community and FIAT's narrative disclosure tone.

In this paper, we use the narrative disclosure tone to assess "tone at the top" rather than relying on aspects related to organizational audit and internal control culture (CoSO, 2011; Hutton et al., 2011; Schwartz et al., 2005), which has been the predominant perspective adopted in the accounting and management literature. As suggested by Amernic et al. (2010), we focus on a disclosure medium that is used by corporate leaders to communicate their attitude and values (i.e., price sensitive press releases). Armenic et al. (2010) analyze CEO letters to shareholders in annual reports and argue that users can gain insights into the "tone at the top" of major companies through this medium due to the possibility to consider both credibility (clear interpretation of corporate events) and responsibility (the degree to which the CEO and top management are good citizens in business relationships) of the communications. These are considered important pillars for defining the tone at the top (Amernic et al., 2010; Weber, 2010). In this study, we analyze the text of price sensitive press releases because, similar to CEO letters in the annual reports, they are read, revised and approved at the highest level of the organization (i.e., the board of directors) before being released to the public.

We examine the disclosures issued by FIAT over a six-year period (2004-2009), during which 70 price-sensitive press releases were published. In contrast to the large 
majority of recent studies, we use a manual procedure to measure disclosure tone (Garcìa Osma and Guillamòn-Saorìn, 2011) based on dictionaries employed by the DICTION software. ${ }^{1}$ Manual coding overcomes the limit of word lists often developed for other disciplines and used in the financial context, which potentially misclassifies common words in that context (Loughran and McDonald, 2011). Manual coding of disclosure tone in FIAT's press releases, news articles and analyst reports allows us to look beyond the tone of words per se and consider the full meaning of the sentence in a particular context. Based on our analysis of 1,887 news articles published in local newspapers, 311 news articles published in international newspapers and 411 analyst reports, we find strong evidence of an interactive process (Ginzel et al., 2004) relationship between the sentiment existing in the local and international press and the financial analysts community and the narrative disclosure tone used by FIAT in its press releases. ${ }^{2}$

In the case of its interaction with the local press, FIAT seems to put in place a counteraction by increasing (decreasing) the optimism of its press releases whenever the sentiment of the local press is low (high). This increase in the optimism of press releases is associated with a positive change in the ex-post sentiment of the local press, suggesting that the potential upward manipulation carried out by FIAT is an effective impression management strategy. ${ }^{3}$ On the other hand, FIAT's relationship with the international press differs slightly. While FIAT seems to set the tone of its press releases independently from the sentiment of the international press, the tone of the corporate language again seems effective as illustrated by the positive association between the increase in the ex-post

\footnotetext{
${ }^{1}$ DICTION is a computerized, dictionary-based content analysis software that examines a text for its communicative or verbal tone across several variables (Hart, 2001).

${ }^{2}$ FIAT's press releases apply to all three audiences, who respond differently to the content of these communications.

${ }^{3} \mathrm{We}$ are aware that there are different aspects and interpretations of impression management. As highlighted in the literature, impression management implies the construction of a public impression by organizational members with the objective to appeal to stakeholders such as shareholders, the media and the general public. The impression conveyed as such may correspond to an "ostensible" reality. Alternatively, it may also entail the enhancement of socially desirable aspects of the organization or the obfuscation of less desirable aspects, hence attempting to manipulate the perceptions of organizational audiences (Gioia et al., 2000).
} 
sentiment of the international press and the increase in the optimistic tone of corporate disclosure. Finally, FIAT's interaction with financial analysts appears to be consistent. FIAT seems to adapt its tone to follow the sentiment of the financial analysts. In other words, if there is a negative variation in the sentiment of financial analysts, FIAT does not appear to challenge the tone in its press releases (as it does with the local press) whereas a positive variation is associated with FIAT increasing the optimistic tone. Once again, this strategy reveals itself to be successful since that particular audience's tone continues to be positively associated with the optimism of the tone in FIAT's press releases. Taken together, these findings point to issues related to assessing the "tone at the top" and potentially raise ethical matters, which are discussed in our conclusion.

This research contributes to the existing literature in three different ways. To the best of our knowledge, this is one of the few studies (Beelitz and Merkl-Davies, 2012; Brennan et al., 2013; Driscoll and Crombie, 2001; Elsbach, 1994) that examines the interactive process between a large organization and three of its key audiences characterized by different levels of power and legitimacy, and aims at determining whether the type of organizational stakeholders has an impact on the use of impression management strategies. Our results also partly build on the work by Neu et al. (1998) on managing public impressions and provide empirical support to the existing impression management framework showing how the company considers each audience and how different information users react to the same message. Finally, it contributes to the impression management literature by showing that firms do use qualitative (i.e., verbal) disclosures to guide the prevailing perceptions existing among various audiences.

The remainder of the paper is structured as follows. The next section provides some background information, a literature review of impression management related studies and the conceptual development. It is followed by the research strategy, design, method, and 
presentation of our empirical results. We close with a discussion and some concluding remarks.

\section{LITERATURE REVIEW AND CONCEPTUAL DEVELOPMENT}

Legitimacy, impression management and organizational audiences

Organizations continually seek to achieve legitimate status - an inherent and logical quest as their relation with members of society at large is bound, directly or indirectly, by a pre-determined social contract. More recently, Suchman (1995) defined organizational legitimacy as "a generalized perception or assumption that the actions of an entity are desirable, proper, or appropriate within some socially constructed system of norms, values, beliefs, and definitions" (p. 574). Hence, it is expected that much effort and considerable resources will be devoted to establishing and/or protecting legitimacy, as this is essential for organizational survival (Ashforth and Gibbs, 1990; Dowling and Pfeffer, 1975).

However, because legitimacy remains dynamic in nature (Lindbolm, 1993), organizations are prone to use thoughtfully prepared "legitimation" strategies to influence or even manipulate public perceptions about their legitimate status (Cho, 2009; Deegan, 2002) — in short, they manage impressions. As such, prior research (e.g., Bansal and Kistruck, 2006; Castelló and Lozano, 2011; Elsbach, 1994; Elsbach and Sutton, 1992; Ginzel, et al., 2004; Livesey and Kearins, 2002) identifies a number of specific impression management tactics adopted by organizations to maintain or enhance their image and reputation, hence managing their legitimacy (Beelitz and Merkl-Davies, 2012). Among these tactics, organizational disclosures constitute an important and effective way to project a positive image and optimally shape the perceptions of firm stakeholders. Such communication strategies ultimately aim to show that the business practices of organizations are aligned with the expected values, norms and beliefs of society (Dowling and Pfeffer, 1975; Lindbolm, 1993). 
Merkl-Davies and Brennan $(2007 ; 2011)$ provide a detailed literature and framework building review of the impression management literature, which naturally fits with Ginzel et al.'s (1994) perspective on the interactive process between organizations and their audiences. Based on their documented classification, impression management communications can be driven by utility maximization (opportunistic); retrospective sense-making to convey an image of organizational rationality (ideological); symbolic management to establish or maintain organizational legitimacy (strategic); and anticipation of users' reactions to prevent the negative impact of information (self-serving). Following Merkl-Davies et al. (2011), we argue that managers are likely to engage in impression management as a means to "counteract undesirable consequences of information releases" (p. 320) and thus prevent adverse reactions (e.g., negative press coverage or unfavorable analyst reports).

As a result, the presentation or disclosure of information can be "systematically biased because of their rationalizing capacities, their ability to avoid responsibility and their inherent ambiguity" (Cho et al., 2010, p. 432). This is referred to as "self-serving reporting bias" through which managers try to control the perception of the various organizational audiences. The interactive process (Ginzel et al., 2004) between managers and audiences can be framed within the social psychology literature, according to which impression management "is embedded in and dependent on management's relationship with organizational audiences" (Merkl-Davies and Brennan, 2011, p. 425) and is therefore intrinsically linked with the relationship between management and its various audiences. Further, the institutional perspective $^{4}$ of organizational legitimacy, suggesting that legitimacy represents a general acceptance and recognition of an entity's practices as appropriate and suitable (Suchman, 1995) and "resides in people's minds" (Breton and Côté, 2006, p. 512), focuses on the role of

\footnotetext{
${ }^{4}$ Beelitz and Merkl-Davies (2012) argue that organizational legitimacy can be conceptualized from two different perspectives - institutional and strategic. The latter perspective focuses on the role of management in building its legitimacy with strategies adopted to restore legitimacy after a crisis or adverse event (managers 'looking out' as an attempt to demonstrate that business practices are aligned with social norms and values).
} 
organizational audiences 'looking in' (Suchman, 1995, p. 577) $)^{5}$ and how the organization is depicted in the media.

The process of managing impressions can generally be divided into two steps: (1) the managerial impression management in corporate-issued documents (e.g., annual reports, sustainability reports, press releases), and (2) the subsequent audience response to those managerial impression management communication strategies.

Few studies concentrate on the interactive process between management and organizational audiences. Elsbach (1994) explores the construction and effectiveness of organizational verbal accounts following controversial events. Her findings suggest that the construction of accounts is explained 'by spokespersons' attempts to provide logical, believable and adequate explanations" and that "the effectiveness of accounts is explained by audiences' perceptions of the type and severity of controversial actions, their expertise in the controversial area and their expectations of organizational responses" (p. 83). Through an analysis conducted to increase their understanding of the role and functioning of environmental disclosures in annual reports, Neu et al. (1998) argue that we not only need to pay attention to the multiplicity of competing "relevant publics"—financial stakeholders, government regulators and environmentalists (see Lindbolm, 1993 for more details on "relevant publics") but also "to the ways in which the relative power of these publics encourage differential disclosure responses" (p. 278). Driscoll and Crombie (2001) investigate the ways through which a company can manage the legitimacy of stakeholders using political language and symbolic activity. Their case study analysis of a conflict between a pulp and paper company and a monastery reveals that both organizational power and stakeholder power are linked to stakeholder legitimacy and that managers tend to be more stakeholder conscious if stakeholders are closer to the company. More recently, Beelitz

\footnotetext{
${ }^{5}$ In contrast to the strategic perspective, under the institutional perspective, the viewpoint of organizational audiences 'looking in' is closely aligned with their perception that organizational practices are congruent with social norms, values and beliefs (Beelitz and Merkl-Davies, 2012).
} 
and Merkl-Davies (2012) use 'CEO-speak' (i.e., “corporate communication”) to analyze CEOs' discourse after a legitimacy-threatening event and find that CEOs attempt to "negotiate a resolution between their initial account and incongruent interpretations by organizational audiences" (p. 109) by adopting an ad hoc normative attitude to stakeholders and use the discourse of stakeholder engagement as a means of signaling change but maintaining the status quo. Brennan et al. (2013) examine CSR disclosure as a reciprocal influence between organizations and their audiences and report evidence of dialogism, which suggests that CSR communication is an interactive process to be understood as a function of power relations between a firm and a specific stakeholder.

A common feature of these previous studies is that they all investigate whether and how organizations use impression management when facing legitimacy crises. In this paper we examine the continuing organization-audience relationship to investigate the use of different disclosure tones by management to influence the impression of its audiences accordingly — hence, we set our context as an ordinary accountability process rather than when the legitimacy of the company is put at risk. This fits well with the "meso-level" analysis approach from Beelitz and Merkl-Davies' (2012) framework as it focuses on the "roles of members of a discourse community and the relationships between them" (p. 105). They further state:

In the case of corporate narratives documents, this [meso-level analysis of discourse analysis] entails analysing the relationship between managers and stakeholders, including regulatory agencies, politicians and intermediaries, such as the media. Both for text producers and recipients, discourse practice also involves issues of unequal discourse access due to asymmetrical power between participants (p. 105).

Tone and language of corporate disclosure

In selecting which specific types of communicative impression management tactics (i.e., corporate disclosures) to adopt, managers may give particular attention to the content, language and/or presentation of information, which can all be used with the objective of 
strategically manipulating the perceptions of stakeholders (Clatworthy and Jones, 2001; Yuthas et al., 2002; see Merkl-Davies and Brennan, 2007 for a complete review). Prior studies have documented the presence of certain language characteristics (Smith and Taffler, 2000; Sydserff and Weetman, 2002) or the effective use of verbal tone and language bias (Aerts, 1994; Cho et al., 2010; Craig et al., 2012) in corporate narratives. In fact, Cho et al. (2010) argue that "the more firm performance differs from a desired benchmark, the more management is motivated to manage impressions, and the more likely it is that narrative disclosure will be affected by a self-serving bias" (p. 432).

While the verbal tone and language used in narrative disclosures are intrinsically unverifiable, they contribute to transfer an impression — assumed to be almost always positive, from the message sender to its receiver. This opportunistic management behavior tends to downplay or obfuscate failure and to emphasize success (Merkl-Davies and Brennan, 2007) by biasing the verbal tone employed in the disclosure narrative. Hence, managing impressions as such provides a means to counteract potential negative consequences to corporate disclosure and enables managers to present "a version of events aimed at winning social and material rewards and avoiding sanctions" (Merkl-Davies and Brennan, 2011, p. 426). According to Cho et al. (2010), "when developing disclosures, management employs thematic manipulation to emphasize good news. In other words, they exhibit a self-serving bias in their selection of firm performance items to disclose and their disclosure includes more positive than negative keywords" (p. 432). Therefore, this suggests that disclosure tone in press releases is expected to emphasize good news by biasing narrative themes through the use of positive keywords.

This type of manipulation has been widely studied in prior literature (e.g. Cho et al., 2010; Merkl-Davies and Brennan, 2007), focusing on whether managers conceal bad news or emphasize positive organizational outcomes, or both. Without explicitly referring to the 
impression management literature, Lang and Lundholm (2000) report that managers increase optimistic disclosure before seasoned equity offerings and their findings seem to support that discretionary disclosure choices affect the perception of investors and analysts. More recently, Schleicher and Walker (2010) investigate the bias of soft information and find that disclosures by firms with impending performance decline use a more optimistic tone. Their results also suggest that firm characteristics (profitability, riskiness) and information environment (analyst following) are associated with a positive tone of narrative disclosure in the annual report, and that the bias in disclosure tone is conducted through a reduction of negative statements. Cho et al. (2010) investigate the bias in the use of language and verbal tone in environmental disclosure as a tool for managing stakeholder impression and find that negative environmental performance is associated with higher levels of environmental disclosure optimism. Finally, Garcìa-Osma and Guillamòn-Saorìn (2011) focus on optimistic disclosure tone, emphasis of positive outcomes and favorable selectivity bias in annual results press releases and report that strong governance limits impression management. Although the theoretical underpinnings of these studies vary, they generally support that firms tend to emphasize positive outcomes with the use of optimistic and positive language (Smith and Taffler, 2000; Rutherford, 2003).

One common way to empirically measure the extent of a narrative's "positiveness" is to measure the degree of language optimism (as previously conducted in prior empirical studies), which is captured through the use of nouns, adjectives, or verbs that are expressing these positive sentiments in the narratives. This is in line with the "micro-level" analysis approach from Beelitz and Merkl-Davies' (2012) analysis framework as it focuses on the "specific linguistic features which are of particular importance for the texts(s) under investigation" (p. 107) and Fairclough (2003), who argues that an essential feature of discourses is vocabulary - the use of keywords, metaphors and differentiation. This level of 
narrative analysis requires first the identification of keywords indicative of themes/subjects represented in the narratives, then that of metaphors and differentiations (Hyland, 1998).

In this paper we focus on how management strategically uses linguistic tone in disclosure to manage and potentially influence the perceptions of different organizational audiences. In order to study the interactive process between the organization and its audiences, we investigate both whether and how management reacts to the existing sentiment of the audiences, and whether and how those impression management strategies have an impact on the sentiment of the audiences.

\section{RESEARCH STRATEGY}

\section{Audiences}

In order to investigate how management interacts with different audiences of corporate disclosures over time, we conduct a longitudinal case study (Yin, 2009) of FIAT. We look at the multi-period interactions that the company has with three key stakeholders characterized by different levels of salience (Mitchell et al., 1997).

The first audience is the local press with whom the company interacts as a representative of the national community. In the domestic context, FIAT constitutes a major player and can significantly affect both economic and social factors. The power dependence in this relationship between FIAT and the national community has developed over time from a mutual dependence (before FIAT's internationalization process) to a firm-dominant oneprimarily because while the company is still considered a contributor to the Italian economy's success, the national community holds both a moral and legal claim on the firm (Mitchell et al., 1997) and can be affected by “the achievement of the organization's objectives" (Freeman, 1984, p. 46). We thus consider this audience as a "dependent stakeholder" characterized by a lack of power but (relatively) urgent and legitimate claims. According to Mitchell et al. (1997), since power in this relationship is not reciprocal, its exercise is most 
likely governed through the guidance of internal management values.

The second audience is the international press as we examine how the company interacts with the international community and manages its relationship with a stakeholder towards which the power exhibited by FIAT is comparatively less strong. This audience still has a legitimate claim over the company, "established through the existence of an exchange relationship who supply the firm with critical resources (contributions) and in exchange each expects its interests to be satisfied (by inducement)" (Hill and Jones, 1992, p. 133). Hence, we classify this audience as a "dominant stakeholder" as it is both powerful and legitimate (Mitchell et al., 1997) and expect that the relationship will highly matter to FIAT.

The third audience - financial analysts, is important because evaluations affect the collective perceptions of investors (Fombrun, 2002; Leuz and Verrecchia, 2000). As information intermediaries, analysts can be seen as "surrogate investors" and contribute significantly to the functioning of the market (Kuperman, 2003). According to Gabbioneta et al. (2007), they represent an important stakeholder in the firm's external environment as they "provide investors with information through their comments, recommendations and interpretations of corporate plans and forecasts tend to affect financial market valuations" (p. 102). The reputation of the company in the eyes of financial analysts will influence their willingness to either provide or withhold support (Gray and Balmer, 1998). We believe that this is a stakeholder-dominant type of relationship as financial analysts represent a group without whose support the company would cease to exist (Ashforth and Gibbs, 1990; Mitchell et al., 1997; Freeman, 1984). In addition, this relationship is also characterized by urgency, which is the degree to which stakeholder claims call for immediate corporate attention (Mitchell et al., 1997). ${ }^{6}$ Therefore, we classify financial analysts as "definitive

\footnotetext{
${ }^{6}$ The urgency of this relationship is well documented by an example reported in Gray and Balmer (1998, p. 698): "The impact of a firm's reputation in the financial community is dramatically illustrated by the changing fortunes of United Airlines. This company, which had been strictly an airline during most of its existence, diversified during the 1980s into hotels and the rent-a-car business, and renamed itself Allegis to reflect its new
} 
stakeholders" as they are characterized by high power, legitimacy and urgency towards which management should have "a clear and immediate mandate to attend to and give priority to that stakeholder's claim" (Mitchell et al., 1997, p. 878).

\section{Research design}

Our analysis is carried out in two steps. We first examine how the existing ex-ante sentiment of different audiences (average optimism level of the local press, the international press and financial analysts, respectively) affects managerial impression management through narrative disclosures. In the second step, we analyze whether and how managerial impression management through narrative disclosure affects the ex-post sentiment of the audiences.

Figure 1 shows our two-step research design and the multi-period relationship between the company and its stakeholders.

\section{[Insert Figure 1 about here]}

Our proxy for managerial impression management is the tone of the narrative disclosure in price-sensitive press releases (PRs). We consider PRs for four reasons. First, companies issue PRs when there are relevant events that may affect the price of stock or of other financial instruments (Henry, 2008; Hirst et al., 2008), thus they are considered relevant overall to organizational audiences. Second, they are widely diffused through media coverage and are generally addressed to a wide range of different stakeholders (Maat, 2007). Third, compared to other corporate documents, PRs can be released any time and focus on specific issues, which represents a timely and direct way to communicate with organizational audiences. Fourth, PRs are formally revised and approved by top managers and hence this allows us to assess the "tone at the top", similarly to what has been done in previous studies assessing the tone at the top through disclosures made by CEOs (Armenic et al., 2010; 
Weber, 2010).

Therefore, we believe that PRs constitutes an adequate corporate disclosure source to examine interaction process between FIAT and its audiences. In parallel, we look at the disclosure tone adopted by the three organizational audiences. In particular we define the "sentiment" of each audience as the average level of optimism in the local press articles, international press articles and financial analyst reports that are issued between two subsequent PRs.

\section{Data collection}

We conduct our analysis over a 6-year period (2004-2009) during which 70 pricesensitive press releases were published. We considered PRs published until January 25, 2010 in order to include communications related to FIAT's performance for 2009. The publication of these PRs does not happen at pre-defined time intervals, but depends on the events shaping corporate activities. In order to measure the optimism in the local press articles, international press articles, and financial analyst reports, we identified each time interval as the period between the dates during which two subsequent press releases were published and considered press articles and analyst reports published during that time interval. As such, the number of local and international press articles and financial analyst reports varies across different time intervals.

\section{Measurement of disclosure tone}

Disclosure tone was measured using a manual multi-step procedure. We conducted the content analysis manually in order to obtain both a full understanding of the real meaning of sentences and creating a complete set of keywords to be used as a reference dictionary.

To examine the tone of price-sensitive press releases, the authors and one research assistant defined four lists of words, each of which was divided into nouns, adjectives and verbs. We needed four lists because we considered positive and negative words both in 
Italian and in English. As preliminary tests, we examined a sample of 40 articles in the Sole24Ore, ${ }^{7} 20$ articles from the Financial Times, 30 analyst reports, and 20 price-sensitive press releases. This allowed us to identify the positive and negative words used. The lists were then integrated by looking at dictionaries employed by the DICTION software ${ }^{8}$ in its various categories. In total we identified 951 words - 245 positive words and 237 negative words in Italian; 235 positive words and 234 negative words in English.

Each sentence was codified using these lists of words. For each PR analyzed, we counted the total number of words and recorded their tone. The tone was determined on the basis of the sentence meaning. For example, the phrase "decrease of loss" would be counted as one positive word, although individually each of the words would be generally associated to a negative sentiment.

All the coding was conducted during the period January - April 2011 by one research assistant under the supervision of one of the authors. On the basis of the evidence collected in a pilot test, a list of identification and classification rules was discussed and defined in order to address potential difficulties in assessing the disclosure tone assigned to a word within a specific sentence. In order to ensure reliability and validity of the data collected, one author and one research assistant repeated the coding procedure over a sample of press releases, press articles and analyst reports until a satisfactory Cronbach's Alpha greater than 0.8 was obtained (Krippendorff, 2004). Appendix 1 provides examples of coding.

Our measure for disclosure tone is labeled Opt $\mathrm{t}_{\mathrm{t}}$ and is computed as follows:

$$
O p t_{t}=\frac{\text { Positive } \text { words }_{t}}{\text { Total words }}
$$

The subscript $t$ indicates the publication date of the PR. We also considered the use of pessimistic tone, calculated as follows:

\footnotetext{
${ }^{7}$ The Sole24Ore is the most influential Italian financial newspaper.

${ }^{8}$ DICTION appears to have gained popularity and validity in the accounting literature, as illustrated by recent studies using the software to analyze various types of texts (e.g., Cho et al., 2010; Craig and Brennan, 2012; Davis and Tama-Sweet, 2011; Fogarty and Rogers, 2005; Mobus, 2011; Rogers et al., 2005).
} 


$$
\text { Pess }_{t}=\frac{\text { Negative words }}{\text { Total words }}
$$

We then determined the overall net optimism by subtracting the pessimistic tone from the optimistic tone.

$$
\text { Net Optimism } \text { Opt }_{t}-\text { Pess }_{t}
$$

\section{Measurement of audience sentiment}

The sentiment of the three audiences is measured with the disclosure tone in financial analyst reports, local press articles and international press articles. Data was collected until February 13, 2010 to allow a three-week period subsequent to the issuance of the last press release analyzed in order to consider the effect of this press release's tone on the audience sentiment.

Local press sentiment was measured by searching articles in the Sole24Ore (the most influential Italian economic newspaper). The Sole24Ore news articles were collected from the Banca Dati database for years $2004-2008^{9}$, for a total of 2,013 news articles. We eliminated all articles where the reference to FIAT was not central and ended up with a final sample of 1,887 articles.

International press sentiment was measured by searching articles in the Financial Times. Data was collected from the Lexis-Nexis database, again considering whether the news articles had FIAT or Marchionne (the CEO) in their headlines. We gathered a total of 375 articles and, once screened using the same method as for the Sole24ore, we obtained 331 articles.

\footnotetext{
${ }^{9}$ Our measure of disclosure tone could be influenced by ancillary comments about the environment, industry or competitors. For both the local and international press, each of the articles in our sample meets certain requirements that we impose to minimize possible noise due to irrelevant news or news that is not strictly focused on FIAT. Specifically, we selected them through a two-step procedure. In the first step, we downloaded from the Lexis-Nexis database all the news articles that mention either the firm's official name in the title/headline or explicitly refer to Mr. Marchionne, its CEO. Then, we read the article and we kept only the articles directly referring to FIAT, its governance, its strategy, its competitive position, its results, etc. We believe that the choice of analyzing only price sensitive press releases and carefully selecting news articles that only focused on FIAT should have minimized the possibility that ancillary comments are influencing our results.
} 
Sentiment of the financial analysts was measured by considering the tone in their reports. Reports by financial analysts were downloaded from the Borsa Italiana's (the Italian Stock Exchange) website for a total of 411 reports. The publication of the reports generally occurs after the quarterly earnings announcements or the issuance of price-sensitive press releases.

The sentiment of each audience preceding a press release was measured as the average tone in the articles or reports between the date of the press release and that of the immediately previous one.

$$
S_{[\mathbf{t}-1, t]}^{i}=\frac{1}{k} \sum_{j=\mathbf{1}}^{k} o p t_{j}^{i}
$$

where:

$o p t_{j}=$ optimistic tone (positive words / total words) of article or report $j$, issued in the period $[\mathrm{t}-1, \mathrm{t}]$ $i=$ Sole24Ore, Financial Times or analyst report

$k=$ number of articles or reports published in the period $[\mathrm{t}-1, \mathrm{t}]$

$\mathrm{t}-1=$ publication date of the previous press release

$\mathrm{t}=$ publication date of the press release

The sentiment of each audience following a press release was measured as the average tone in the articles or reports between the date of the press release and that of the immediately following one.

$$
S_{[\mathbf{L}, t+1]}^{i}=\frac{1}{k} \sum_{j=\mathbf{1}}^{k} o p t_{j}^{i}
$$

where:

$o p t_{j}=$ optimistic tone (positive words / total words) of article or report $j$, issued in the period [t, $\left.\mathrm{t}+1\right]$ $i=$ Sole24Ore, Financial Times or analyst report

$k=$ number of articles or reports published in the period $[\mathrm{t}, \mathrm{t}+1]$

$\mathrm{t}=$ publication date of the press release

$\mathrm{t}+1=$ publication date of the subsequent press release

If any articles or reports were released exactly at time $t$, they would not be considered. 


\section{Data analysis}

We start our analysis by examining the effect of the pre-existing sentiment of audiences on corporate disclosure tone. We estimate three OLS models-one for each the organizational audiences.

$O p t_{t}=\beta_{0}+\beta_{1} S_{[t-1, t]}^{i}+\beta_{2} \operatorname{LnEBIT}+\beta_{3} \operatorname{Rend}_{[t-1, t]}+\beta_{\mathbf{4}} E A Q+\beta_{\mathbf{5}} \operatorname{Number}_{[\mathrm{t}-1, t]}^{i}+\beta_{7} \operatorname{LnOpt}_{t-\mathbf{1}}+\varepsilon$

$O p t_{t}$ is the optimistic tone in the PR released in date $t, S_{[t-1, t]}^{i}$ is the sentiment of audience $i$ where $i$ refer to the audience local press (Sole24Ore), international press (Financial Times) and financial analysts. Following Rogers et al. (2010) and Davis, Piger and Sedor (2012), we consider the logarithmic transformation of EBIT (LnEBIT) in order to control for the role played by the underlying performance of the company of the last reported quarter. We also considered the market return (Rend) determined as $\left[\left(\mathrm{P}_{\mathrm{t}}-\mathrm{P}_{\mathrm{t}-1}\right) / \mathrm{P}_{\mathrm{t}-1}\right]-\left[\left(\mathrm{M}_{\mathrm{t}}-\mathrm{M}_{\mathrm{t}-1}\right) / \mathrm{M}_{\mathrm{t}-1}\right]$, where $\mathrm{P}_{\mathrm{t}}$ and $\mathrm{M}_{\mathrm{t}}$ are the price of FIAT stock at $t$, i.e., the day on which price-sensitive information is released, and the average market return for the FTSE MIB index at $t$, respectively. Similarly, $\mathrm{P}_{\mathrm{t}-1}$ is the price of the share at $t$-1, i.e., the day on which immediately previous price-sensitive information was released and $\mathrm{M}_{\mathrm{t}-1}$ is the average market return for the FTSE MIB index at $t-1$. We also considered whether PR is an earnings press release and if so, during which quarter it is released. We created an ordinal variable, $E A Q$, which takes the value of the quarter it refers to ( 1 for the first quarter, 2 for the second, 3 for the third and 4 for the fourth) if it is an earnings announcement, and zero otherwise. We also control for the number of articles or reports issued (number) during the period [t-1, t]. If $i=$ analyst reports, we also control for the total sentiment of the audience $\left(\operatorname{Tot}_{\mathrm{L}-1, t \mathbf{l}}^{i}\right)$ measured as the average sentiment multiplied by the number of reports issued $\left(\right.$ Number $\left.^{i} * S_{[t-1, t]}^{i}\right)$. Finally, we control for the disclosure tone in the immediately previous PR ( LnOpt $\left._{t-1}\right)$.

We also consider that the relationship between the existing sentiment of the audience and the disclosure tone $\left(o p t_{t}\right)$ may not be linear, and that the intensity of the relation is 
decreasing with the increase of the average sentiment of the audiences. As such, we estimate our model using the logarithm of the existing sentiment.

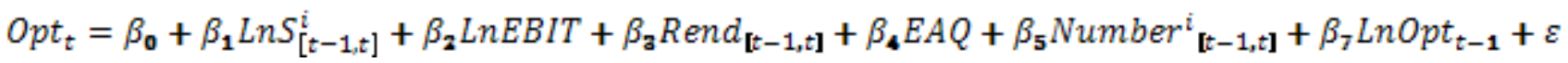

We adopt the same approach to investigate the effect of corporate disclosure tone over the following sentiment of the audiences. We thus estimate again three OLS models-one for each of the organizational audiences considered.

$S_{[t, t+1]}^{i}=\beta_{0}+\beta_{\mathbf{1}} O p t_{t}+\beta_{\mathbf{2}} \operatorname{LnEBIT}+\beta_{\mathbf{3}} \operatorname{Rend}_{[\mathbf{t}-1, \mathrm{t}] \mathrm{t}}+\beta_{\mathbf{4}} E A Q+\beta_{\mathbf{5}} \operatorname{Ln} S_{[t-1, t]}^{i}+\varepsilon$

where ${ }^{\left.S^{i}, t+1+1\right]}$ is the sentiment of audience $i$ where $i$ refer to the audience local press

(Sole24Ore), international press (Financial Times) and financial analysts. ${ }^{S_{[t-1, t]}^{i}}$ is the sentiment of audience $i$ where $i$ refer to the audience local press (Sole24Ore), international press (Financial Times) and financial analysts in the previous period. The other variables are defined as above. Table 1 summarizes the labels, measurements and proxies of the variables adopted in the study.

[Insert Table 1 about here]

Similar to the first step, it is plausible that the intensity of the relation is decreasing with the increase of the disclosure tone. Therefore, we use the logarithm of the disclosure tone $\left(o p t_{t}\right)$ to consider the possible decreasing marginal effect:

$S_{[t, t+1]}^{i}=\beta_{0}+\beta_{1} \operatorname{LnOpt}_{t}+\beta_{\mathbf{2}} \operatorname{LnEBIT}+\beta_{\mathbf{3}} \operatorname{Rend}_{[\mathrm{t}-1, t]}+\beta_{\mathbf{4}} E A Q+\beta_{5} \operatorname{Ln} S_{[t-1, t]}^{i}+\varepsilon$

\section{RESULTS}

\section{$\underline{\text { Descriptive analysis }}$}

Table 2 shows descriptive statistics for corporate disclosure tone. Panel A provides information about all press releases. On average, the length of the press releases is 2,766 
words with 61 positive words and almost 35 negative ${ }^{10}$ ones. A descriptive analysis of corporate disclosure tone has also been conducted according to the content of the press releases, which we grouped into three categories - Industrial Relations, Results, and Strategy, according to the main heading of the PR itself. Panel B presents the descriptive statistics for the six press releases referring to "Industrial relations". On average, these press releases have 749 words, with a predominance of negative words (17 against almost 8 positive); hence the overall net optimism of this type of press release is on average negative $(-1.3 \%)$. Panel C shows that press releases focusing on "Results" are generally longer (5,064 words), contain 117 positive words and 69 negative ones, with a consequent net optimism of $1 \%$. Finally, Panel D indicates that press releases on "Strategy" have, on average, 711 words, with 12 positive words and 2 negative ones. The overall net optimism is positive and equal to $1.4 \%$. All mean scores for net optimism are significantly different from zero, suggesting that the tone in the press releases is not neutral.

We also conducted a binomial probability test, which indicates that the difference in proportion of press releases with a more optimistic than pessimistic tone is statistically significant (at $\mathrm{p} \leq .001$ ). This test suggests a "selectivity bias" in the choice of reporting press releases that contain a higher number of optimistic than pessimistic words.

[Insert Table 2 about here]

Table 3 shows descriptive statistics for the sentiment of the audiences. Panel A presents all 2,629 documents analyzed with each document containing 506 words on average, most of which are positive. Panels B, C, and D show the breakdown of the descriptive statistics according to the audience being analyzed - the local press, the international press and financial analysts, respectively. Evidence suggests that, on average, analyst reports are longer (1,069 words vs. 399 words in articles published in the local press and 418 words in

\footnotetext{
${ }^{10}$ Negative words are counted to measure the pessimistic tone of the press release, calculated as Negative Words divided by Total Words). In further analyses, it is used to determine the net optimistic tone of each press release, calculated as Optimism minus Pessimism.
} 
the international articles). All documents analyzed generally have a greater number of positive than negative words, the local press indicating more variation in net optimism (minimum is equal to -0.051 and maximum is equal to 0.091 ) and financial analysts being the more optimistic of the three audiences as illustrated by the average value for the sentiment (optimism) of 3\%. All mean scores for net optimism are significantly different from zero, suggesting that the tone in the local and international press and in analyst reports is not neutral.

\section{[Insert Table 3 about here]}

\section{$\underline{\text { Univariate analysis }}$}

Table 4 presents the univariate tests for differences in the average sentiment of the three audiences. Tests are conducted using both the average optimistic tone of the documents (results are shown in the right upper cells) and the average net optimistic tone, thus considering also the presence of negative words (left lower cells). The differences are computed by subtracting the sentiment of the audience shown in the column head from the sentiment of the audience indicated in the table row. The univariate analysis confirms that financial analysts are the most optimistic (compared to both the local and international press) and that the local press is more optimistic than the international press, although the significance level is only at $10 \%$. Moreover, when we control for the presence of negative words, thus focusing on the net optimism, we find similar evidence; that is, analyst reports present a greater average sentiment than international (1\% significance level) and local press (10\% significance level), and local press shows greater average sentiment than the international one (10\% significance level).

[Insert Table 4 about here]

Table 5 presents the correlation analysis. Corporate optimistic tone $\left(o p t_{t}\right)$ is positively correlated with the sentiment of the international press in the period preceding the press 
releases $\left(S^{\mathrm{FT}}[\mathrm{t}-1, \mathrm{t}]\right)$, but not with the sentiment of the other two audiences. $O p t_{t}$ is also positively correlated with the ex-post sentiment of all three audiences, although with different intensity. As expected, the level of optimism of the press releases is also correlated with the financial performance of the firm $(L n E B I T)$ as well as with the fact that the press releases report on quarterly earnings.

[Insert Table 5 about here]

\section{$\underline{\text { Multivariate analysis }}$}

Table 6 presents the results of multivariate regression analyses. Column 1 shows results of the relation between the existing sentiment of the local press (Sole24Ore) and the optimism of the press releases issued at $t$. We also consider a regression model in which we use the logarithmic transformation of the sentiment. In both cases, the coefficient is significant and negative, which suggests that as the sentiment of the local press is less optimistic, the disclosure tone of the company tends to be higher (and vice versa). This provides evidence that FIAT anticipates the evaluation of the local press by adjusting the disclosure tone in its corporate press releases.

[Insert Table 6 about here]

Column 2 shows the results regarding the relation between FIAT and the international press. Neither coefficient for $S_{[t-1, t]}^{i}$ and $\log \left(S_{[t-1, t]}\right)$ is significant, suggesting that the company does not consider the sentiment of the international press and does not adjust the tone of corporate disclosure accordingly.

Finally, column 3 shows regression results for the association between the sentiment of financial analysts and the tone of FIAT's press releases. In this case, the coefficients for $S_{[t-1, t]}^{i}$ and $\log \left(S_{[t-1, t]}^{\mathrm{i}_{1}}\right)$ are both positive and significant, which indicates that the optimistic tone in analyst reports is positively associated with the optimistic tone in the company's press releases. 
For all models, there is evidence that the optimism of the corporate disclosure is positively associated with the financial performance and the release of quarterly results. In the case of financial analysts, a positive association is found between the number of reports issued by the financial analyst community during the time interval between the two dates of subsequent press releases and their disclosure tone; that is, the higher is the number of reports issued by financial analysts, the higher the optimism level of FIAT's press releases. On the other hand, this effect is moderated when there is a large number of reports and they are, on average, highly optimistic as shown by the negative and significant coefficient for the total sentiment of financial analysts.

Results for the second step of our analysis are reported in Table 7. Columns (1), (2), and (3) show the local press, international press and financial analysts, respectively, respond to FIAT's press releases. Results indicate a significant and positive relation between the tone of the press release and the ex-post tone of each audience. In other words, all three audiences are positively affected by the disclosure tone of press releases. This suggests that an optimistic tone in corporate press releases appears to have an impact on the sentiment of the audience.

\section{[Insert Table 7 about here]}

Another interesting result of this analysis is the different "consistencies" of the three organizational audiences. While the local press seems to be not consistent $\left(\operatorname{Ln} S_{[t-1, t]}^{\mathrm{i}}\right)$, the sentiment in the previous period is not significant), the international press appears to have a "mild consistency" (we have one model with a positive and significant coefficient at $10 \%$ ) and financial analysts are those with a "strong consistency" (they will have a more optimistic sentiment if their sentiment in the previous period was high, as supported by a positive and strongly significant coefficient). Results show that the optimistic sentiment of the international press is negatively related to the communication of financial results (quarterly 
earnings announcement); that is, when the press release is an earnings announcement, the sentiment of the international press is characterized by less optimism. We also find the optimistic sentiment of the international press is lower at the end of the fiscal year than it is at the beginning of the fiscal year; that is, articles closer to the end of the fiscal year show less optimism than articles closer to the beginning of the fiscal year. Finally, the sentiment of financial analysts is also associated with FIAT's market performance (the coefficient for market returns, Rend, is positive and statistically significant).

An important issue in our empirical analysis consists of determining whether there is a causal relationship between FIAT's tone and the market's sentiment. We address the issue of the direction of causality using lagged variables (sentiment in $t-1$ as a predictor of the disclosure tone in $t$ and disclosure tone in $t$ as a predictor for the sentiment in $t+1$ ). This approach, however, does not completely solve the causality issue and guarantee the efficiency of the estimation because of the simultaneity of the decision about the tone to be used in the press release in $t$ (formed through the period $t-1$ ) and the sentiment in the period $t-1$. Hence, we address this issue by estimating a three-stage least square model (3SLS) with simultaneous equations that consider the tone of the disclosure in $t$ and the sentiment in $t-1$ as jointly determined through a system of equations.

Table 8 shows the results of this additional analysis and Figure 2 summarizes the interaction process between FIAT and each of the audiences analyzed.

[Insert Table 8 about here]

The evidence seems to support that FIAT is able to manage the impression of its audiences even when it does anticipate their evaluations.

\section{Additional analyses}

We performed several tests to ensure the robustness of our results. We first re-ran our analysis considering a more conservative measure of disclosure tone, i.e. the net optimism, 
determined as the difference between positive and negative words (a measure that includes also the "pessimistic" tone of the press releases). Similarly, the sentiment of the audiences was determined considering also the use of negative words in the articles or reports analyzed. As documented in Table 9 and 10, our results hold.

\section{[Insert Tables 9 and 10 about here]}

Tables 11 and 12 show another similar analysis, where we measure the dependent variables of our models as respectively:

1) the percentage variation of press release optimism

$$
\frac{o p t_{t}-o p t_{t_{-1}}}{o p t_{t_{-1}}}
$$

$$
\frac{S_{[t, t+1]}^{i}-S_{[t-1, t]}^{i}}{S_{[t-1, t]}^{i}}
$$

By using a measure of variation we intend to further address the concern over causality between FIAT's tone and the sentiment of the market. Indeed, in the first step analysis, considering the variation of our dependent variable $O p t_{t}$, we can test whether the sentiment of each audience determines a change in FIAT's press release tone rather than simply investigating whether there is an association between the two variables. Similarly, considering the variation in the sentiment of each audience before and after the press release allows us to make inferences on whether the press release tone leads to an actual change in the sentiment of each audience. Our results remain similar except that we lose significance for the relation between the tone of FIAT's press releases and the existing sentiment of financial analysts as well as in the subsequent relationship between the tone of FIAT's press releases and the ex-post sentiment diffused among financial analysts.

[Insert Tables 11 and 12 about here]

Based on the findings of the main and additional analyses, Figure 2 summarizes the interaction process between FIAT and each of the audiences analyzed. 
[Insert Figure 2 about here]

Finally, un-tabulated results provide evidence similar to that presented in Tables 6 to 12 if we use alternative measures for financial performance and size. We repeat the analyses controlling whether the "main content" of the press release (Industrial Relations, Results, and Strategy) affect our findings and we obtain results that are qualitatively similar to those reported in the main analysis. We also obtain similar results when we control for wider economic factors (general trend of the Italian financial market index during each window of time considered) that might be driving the optimism of FIAT or the sentiment of each audience.

\section{DISCUSSION AND CONCLUSIONS}

Previous studies found that managers use bias in disclosure tone to manage the impression of stakeholders particularly when facing a legitimacy threat (e.g., Beelitz and Merkl-Davies, 2012; Driscoll and Crombie, 2001; Elsbach, 1994). This paper extends this research stream by using a one-firm, longitudinal multi-period case study conducted to investigate the interactive relationship (Ginzel et al., 1994) between FIAT, a major player in the Italian economy, and three of its key organizational audiences during the regular course of business rather than in response to a specific event for which corporate communication might be used ad hoc to restore and repair lost or damaged legitimacy. Further, when examining the interactive process between FIAT and its key organizational audienceswhich are characterized by different levels of power, legitimacy and urgency, we seek to understand whether the type of stakeholders to whom the company is accountable has an impact on the use of impression management and, in particular, optimistic tone in corporate disclosure.

Focusing on FIAT's corporate disclosures, we first investigated whether and how the company reacts in terms of disclosure tone to the existing sentiment in the local and 
international press or diffused among financial analysts, and further examined whether and how disclosure tone appears to influence the ex-post sentiment of each organizational audience. Our results indicate some differences in the way FIAT's tone relates to the sentiment of each audience, hence highlighting that the salience of the stakeholder is an important driver of the adoption of impression management even in the ordinary course of business, without the occurrence of a legitimacy threatening event.

For the local press (dependent stakeholder), there is a negative relation between the tone of corporate press releases and the sentiment of local press. This suggests that when the sentiment of the local press decreases (i.e., it becomes less optimistic), FIAT puts in place a counteraction by increasing the optimism of its press releases. This increase in the optimism of press releases in turn leads to a positive change in the ex-post sentiment of the local press (i.e., the local press improves its sentiment in the period following the press releases) as shown in the first graph of Figure 2. Therefore, such communication strategy carried out by FIAT can be seen as an effective impression management tactic as it leads to the desired outcome.

On the other hand, the relationship with the international press (dominant stakeholder) is slightly different. FIAT seems to set the tone of its press releases regardless of the sentiment exhibited by the international press (i.e., a change in the sentiment of the international press does not cause a variation in the tone of press releases), suggesting that the company does not anticipate the evaluation of the international press when setting the tone of its press releases. Nevertheless, the tone of the language in the press releases seems influential and effective as the increase in the ex-post sentiment of the international press is positively associated with the increase in the optimistic tone of corporate disclosure.

Finally, the relationship between FIAT and the financial analysts (definitive stakeholder characterized by high power, legitimacy and urgency) seems to be consistent. In 
the first part of the relationship, FIAT adapts its tone and follows the sentiment of the financial analysts; that is, if there is a positive variation in the sentiment of financial analysts, FIAT also increases the optimistic tone of its press releases. However, when there is a negative variation in the tone of analyst reports, the company does not challenge the tone (as it does with the local press). This behavior, again, leads FIAT to successfully influence the perceptions of its audience, particularly in that this audience remains positively associated with its press releases' optimistic tone. Indeed, we report a positive and significant relationship between corporate disclosure tone and the ex-post sentiment of financial analyst reports.

In conclusion, our evidence suggests that the narrative disclosure tone in FIAT seems to be used as a means to affect the sentiment in financial markets rather than to fully reflect corporate performance. Further, the use of such tone appears to be carefully planned, crafted and strategically customized for each targeted organizational audience and the power relations with these audiences seem to play a significant role, as illustrated by different usages for "dependent", "dominant" and "definitive" stakeholders, respectively. Given that we do not have evidence about the intention of the preparers to manage the impressions of stakeholders (Beattie and Jones, 1999), we are not able to claim that disclosure tone is inherently and systematically about bias and manipulation. Indeed, our evidence could simply indicate that managers are seeking to manage important and influential stakeholders or pricemaker market participants in a way that is consistent with endeavouring to enhance shareholder value. Nevertheless, and similar to what Neu et al. (1998) report, this finding is consistent with the proposal that in conflicting interest situations, organizations seek to communicate legitimating characteristics to the most important relevant publics and dismiss or ignore less important ones (Oliver, 1991). Further, Beelitz and Merkl-Davies (2012) state that the "the strategic use of discourse as a means of resolving a conflict between the 
organisation and its audiences by means of signaling that it has realigned its norms and values with that of society" (p. 105) represents an ethical issue as it (1) "entails influencing organisational audiences' ideas and managing their perceptions as a means to manufacturing their consent" (p. 105); (2) mostly occurs "in a way that benefits the company at the expense of society" (p. 115); and (3) "sustains relations of domination" (p. 116). While the disclosure practices examined in our case study of FIAT are not directly related to specific events, conflicts, or (lack of or negative) performance, we argue that the narrative disclosure tone in FIAT can lead to a strategic use of different corporate discourse tones driven by the salience of the targeted stakeholder audience, which could in turn potentially constitutes opportunistic behavior as a device for impression management. In such a case, this impression management tactic would be similar to the ones used to avoid responsibility for poor performance (Giacolone and Pollard, 1987) or to make "self-depreciating statements in an attempt to evoke sympathy from the target" (Goffman, 1971, as cited in Moberg, 1989, p. 179) — “these impression management behaviors are unethical since they may result in undeserved rewards" (Moberg, 1989, p. 179).

As in all investigations, ours is subject to limitations. Because this study is based on the analysis of a single company interacting with three selected audiences, the extent to which the results are generalizable cannot be determined - a common issue inherent to case studies in general. Our study is also couched under a specific context and somewhat limited time period, which prevents us from drawing broader and more comprehensive conclusions about whether our findings would hold across time periods and under a different context. Finally, while we show different strategic patterns exist in the interaction processes between FIAT and its audiences, and that there are some differences in the way FIAT is affected by, and in turn, affects the sentiment of each audience, we do not have strong supporting 
evidence about whether these patterns are a result of management intent. As such, extensions of our work along each of these limiting dimensions would appear to be warranted. 


\section{REFERENCES}

Aerts, W. (1994). On the use of accounting logic as an explanatory category in narrative accounting disclosures. Accounting, Organizations and Society, 19(4/5), 337-353.

Amernic, J., Craig, R., \& Tourish, D. (2010). Measuring and assessing tone at the top using annual report CEO letters. Edinburgh: The Institute of Chartered Accountants of Scotland.

Ashforth, B. E., \& Gibbs, B. W. (1990). The double-edge of legitimization. Organization Science, 1(2), 177-194.

Baginski, S., Demers, E., Wang, C., \& Yu, J. (2011). Understanding the role of language in management forecast press releases. INSEAD Working paper collection, 2011/28/AC.

Bansal, P., \& Kistruck, G. (2006). Seeing is (not) believing: Managing the impressions of the firm's natural commitment to the natural environment. Journal of Business Ethics, 67(2), 165-180.

Beattie, V., \& Jones, M. J. (1999), Australian financial graphs: An empirical study, Abacus $35(1), 46-76$.

Beelitz, A., \& Merkl-Davies, D. M. (2012). Using discourse to restore organisational legitimacy: 'CEO-speak' after an incident in a German nuclear power plant. Journal of Business Ethics, 108(1), 101-120.

Brennan, N. M., Merkl-Davies, D. M., \& Beelitz, A. (2013). Dialogism in corporate social responsibility communications : Conceptualising verbal interaction between organisations and their audiences. Journal of Business Ethics, 115(4), 665-679.

Breton, G., \& Côté, L. (2006). Profit and the legitimacy of the Canadian banking industry. Accounting, Auditing and Accountability Journal, 19(2), 512-539.

Castelló, I., \& Lozano, J. M. (2011). Searching for new forms of legitimacy through corporate responsibility rhetoric. Journal of Business Ethics, 100(1), 11-29

Cho, C. H. (2009). Legitimation strategies used in response to environmental disaster: A French case study of Total's SA's Erika and AZF incidents. European Accounting Review, 18(1), 33-62.

Cho, C. H., Roberts, R. W., \& Patten, D. M. (2010), The language of US corporate environmental disclosure. Accounting, Organization and Society, 35(4), 431-443.

Clatworthy, M., \& Jones, M. J. (2001). The effect of thematic structure on the variability of annual report reliability. Accounting, Auditing and Accountability Journal, 14(3), 311326.

CoSO (Committee of Sponsoring Organizations of the Treadway Commission) (2011). Internal Control - Integrated Framework. AICPA, Jersey City, NJ.

Craig, R. J., \& Brennan, N. M. (2012). An exploration of the relationship between language choice in CEO letters to shareholders and corporate reputation. Accounting Forum, 36(3), 166-177.

Craig, R., Mortensen, T., \& Iyer, S. (2012). Exploring top management language for signals of possible deceptions: The words of Satyam's chair Ramalinga Raju. Journal of Business Ethics (available online: DOI: 10.1007/s10551-012-1307-5).

Davis, A. K., \& Tama-Sweet, I. (2011). Managers' use of language across alternative disclosure outlets: Earnings press releases versus MD\&A. Contemporary Accounting Research, 20(10), 1-34.

Davis, K. A., Piger, J. M., \& Sedor, L. M., (2012). Beyond the numbers: Measuring the information content of earnings press release language. Contemporary Accounting Research, 29(3), 845-868.

Deegan, C. (2002). The legitimizing effect of social and environmental disclosures: A theoretical foundation, Accounting, Auditing and Accountability Journal, 15(3), 282-311. 
Dowling, J., \& Pfeffer, J. (1975) Organizational legitimacy: Social values and organizational behavior. Pacific Sociological Review, 18(1), 122-136.

Driscoll, C., \& Crombie, A. (2001). Stakeholder legitimacy management and the qualified good neighbor: The case of Nova Nada and JDI. Business \& Society, 40(4), 442-471

Elsbach, K. D. (1994). Managing organizational legitimacy in the California cattle industry: The construction and effectiveness of verbal accounts. Administrative Science Quarterly, 39(1), 57-88.

Elsbach, K. D., \& Sutton, R. I. (1992). Acquiring organizational legitimacy through illegitimate actions: A marriage of institutional and impression management theories. Academy of Management Journal, 35(4), 699-738.

Fairclough, N. (2003). Analysing discourse: Text analysis for social research. London: Routledge.

Feldman, R., Govindaraj, S., Livnat, J., \& Segal, B. (2010). Management's tone change, post earnings announcement drift and accruals. Review of Accounting Studies, 15, 915-953.

Fogarty T. J., \& Rogers, R. K. (2005). Financial analysts' reports: An extended institutional theory valuation. Accounting, Organizations and Society, 30(4), 331-356.

Fombrun, C. J. (2002). Corporate reputations as economic assets. In M. Hitt et al. (Eds.), Handbook of strategic management, Oxford: Blackwell.

Freeman, R. E. (1984). Strategic management: A stakeholder approach, Boston, MA: Pitman.

Gabbioneta, C., Ravasi, D., \& Mazzola, P. (2007). Exploring the drivers of corporate reputation: A study of Italian security analysts. Corporate Reputation Review, 10(2), 99123.

Garcìa Osma, B., \& Guillamón-Saorín E. (2011). Corporate governance and impression management in annual results press releases. Accounting, Organizations and Society, 36(4-5), 187-208.

Giacalone, R. A., \& Pollard, H. G. (1987). The efficacy of accounts for a breach of confidentiality by management. Journal of Business Ethics, 6, 393-397.

Ginzel, L. E., Kramer, R. M., \& Sutton, R. I. (2004). Organizational impression management as reciprocal influence process: The neglected role of the organisational audience. In M. J. Hatch \& M. Schultz (Eds.), Organizational identity (pp. 223-261). Oxford, UK: Oxford University Press.

Gioia, D. A., Schultz, M., \& Corley, K. G. (2000). Organisational identity, image, and adaptive instability. Academy of Management Review, 25(1), 63-81.

Goffman, E. (1971). Relations in public: Micro-studies of the public order. Harmondsworth, UK: Penguin.

Gray, E. R., \& Balmer, J. M. T. (1998). Managing corporate image and corporate reputation. Long Range Planning, 31(5), 695-702

Hart, R. P. (2001). Redeveloping DICTION: Theoretical considerations. In M. D. West (Ed.). Theory, method, and practice of computer content analysis (pp. 43-60). Westport, CT: Greenwood Publishing Group.

Henry, E. (2008). Are investors influenced by how earnings press releases are written? Journal of Business Communication, 45(4), 367-407.

Hill, C. W. L., \& Jones, T. M. (1992). Stakeholder-agency theory. Journal of Management Studies, 29(2), 131-154.

Hirst, D. E., Koonce, L., \& Venkataraman, S. (2008). Management earnings forecasts: A review and framework. Accounting Horizons, 22(3), 315-338.

Hutton, J. E., Hoitash, R., \& Thibodeau, J. C. (2011). The relationship between perceived tone at the top and earnings quality. Contemporary Accounting Review 28(4), 1190-1224. 
Hyland, K. (1998). Exploring corporate rhetoric: Metadiscourse in the CEO's letter. Journal of Business Communication, 35(2), 224-245.

Krippendorff, K. (2004). Content analysis: An introduction to its methodology, $2^{\text {nd }}$ ed., Thousand Oaks, CA: Sage.

Kuperman, J. C., (2003). Using cognitive schema theory in the development of public relations strategy: Exploring the case of firms and financial analysts following acquisition announcement. Journal of Public Relations Research, 15(2), 117-150.

Lang, M. H., \& Lundholm, R. J. (2000). Voluntary disclosure and equity offerings: Reducing information asymmetry or hyping the stock? Contemporary Accounting Research, 17(4), 623-662.

Leuz, C., \& Verrecchia, R. E. (2000). The economic consequences of increased disclosure. Journal of Accounting Research, 38(3), 49-77.

Lindbolm, C. K. (1993). The implications of organizational legitimacy for corporate social performance and disclosure. Paper presented at the Critical Perspectives on Accounting Conference, New York, NY.

Livesey, S. \& Kearins, K. (2002). Transparent and caring corporations? Organization \& Environment, 15(3), 233-258.

Loughran, T., \& McDonald, B. (2011). When is a liability not a liability? Textual analysis, dictionaries, and 10-Ks. Journal of Finance, 66(1), 35-65.

Maat, H. P. (2007). How promotional language in press releases is dealt with by journalists: Genre mixing or genre conflict. Journal of Business Communication, 44, 59-95.

Merkl-Davies, D. M., Brennan, N. M., \& McLeay, S. J. (2011). Impression management and retrospective sense-making in corporate narratives: A social psychology perspective. Accounting, Auditing and Accountability Journal, 24(3), 315-344.

Merkl-Davies, D., \& Brennan, N. (2007). Discretionary disclosure strategies in corporate narratives: Incremental information or impression management? Journal of Accounting Literature, 26, 116-196

Merkl-Davies, D., \& Brennan, N. (2011). A conceptual framework of impression management: New insights from psychology, sociology and critical perspectives. Accounting and Business Research, 41(5), 415-437

Mitchell, R. K., Agle, B. R., \& Wood, D. J. (1997). Towards a theory of stakeholder identification: Defining the principle of who and what really counts. Academy of Management Review, 22(4), 853-886.

Moberg, D. J. (1989). The ethics of impression management. In R. A. Giacolone and P. Rosenfeld (Eds.). Impression management in the organization (pp. 171-188). Hillsdale, NJ: Lawrence Erlbaum Associates, Inc.

Mobus, J. L. (2011). Developing collective intentionality and writing the rules of the game for environmental reporting: A content analysis of SOP 96-1 comment letters. Accounting and the Public Interest, 11(1), 68-95.

Neu, D., Warsame, H., \& Pedwell, K. (1998). Managing public impressions: Environmental disclosures in annual reports. Accounting, Organizations and Society, 23(3), 265-282.

Oliver, C. (1991). Strategic responses to institutional processes. Academy of Management Review, 15, 145-179.

Price, M. S., Doran, J. S., Peterson, D. R., \& Bliss B. B. (2012). Earnings conference calls and stock returns: the incremental informativeness of textual tone. Journal of Banking and Finance, 36, 992-1011

Rogers, R., Dillard, J., \& Yuthas, K. (2005). The accounting profession: Substantive change and/or image management. Journal of Business Ethics, 58(1/3), 159-176.

Rogers, J. L., Van Buskirk, A., \& Zechman, S. L. (2010). Disclosure tone and shareholder litigation. Working paper. 
Rutherford, B. A. (2003). Obfuscation, textual complexity and the role of regulated narrative accounting disclosure in governance. Journal of Management and Governance, 7, 187210.

Schleicher, T., \& Walker, M. (2010). Bias in the tone of forward-looking narratives. Accounting and Business Research, 40(4), 371-390.

Schwarz, M.S., Dunfee, T.W. \& Kline, M.J. (2005). Tone at the top: An ethics code for directors? Journal of Business Ethics 58(1-3), 79-100.

Smith, M., \& Taffler, R. J. (2000). The chairman's statement: A content analysis of discretionary narrative disclosures. Accounting, Auditing and Accountability Journal, 13(5), 624-646.

Suchman, M. C. (1995) Managing legitimacy: Strategic and institutional approaches. Academy of Management Review, 20, 571-610.

Sydserff, R., \& Weetman, P. (2002). Development in content analysis: A transitivity index and DICTION scores. Accounting, Auditing and Accountability Journal, 15(4), 523-545.

Yin, R. K. (2009). Case study research: Design and methods, $4^{\text {th }}$ ed., Thousand Oaks, CA: Sage.

Yuthas, K., Rogers, R., \& Dillard, J. (2002). Communicative action and corporate annual reports. Journal of Business Ethics, 41(1-2), 141-157.

Weber, J. (2010). Assessing the "tone at the top": The moral reasoning of CEOs in the automobile industry. Journal of Business Ethics, 92(2), 167-182 


\section{Figure 1. Research design}

Step 1. How does the sentiment of the audience affect the tone of disclosure of the press release?

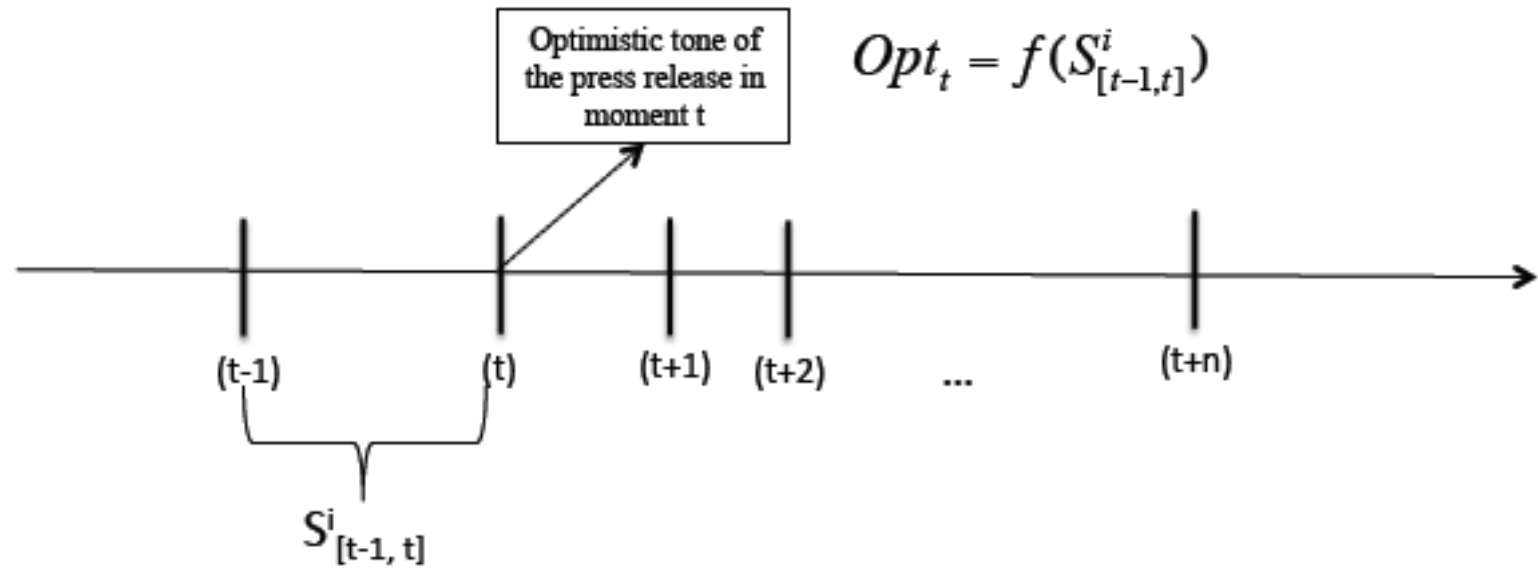

Step 2. How do audiences react to the tone of disclosure of the press release?

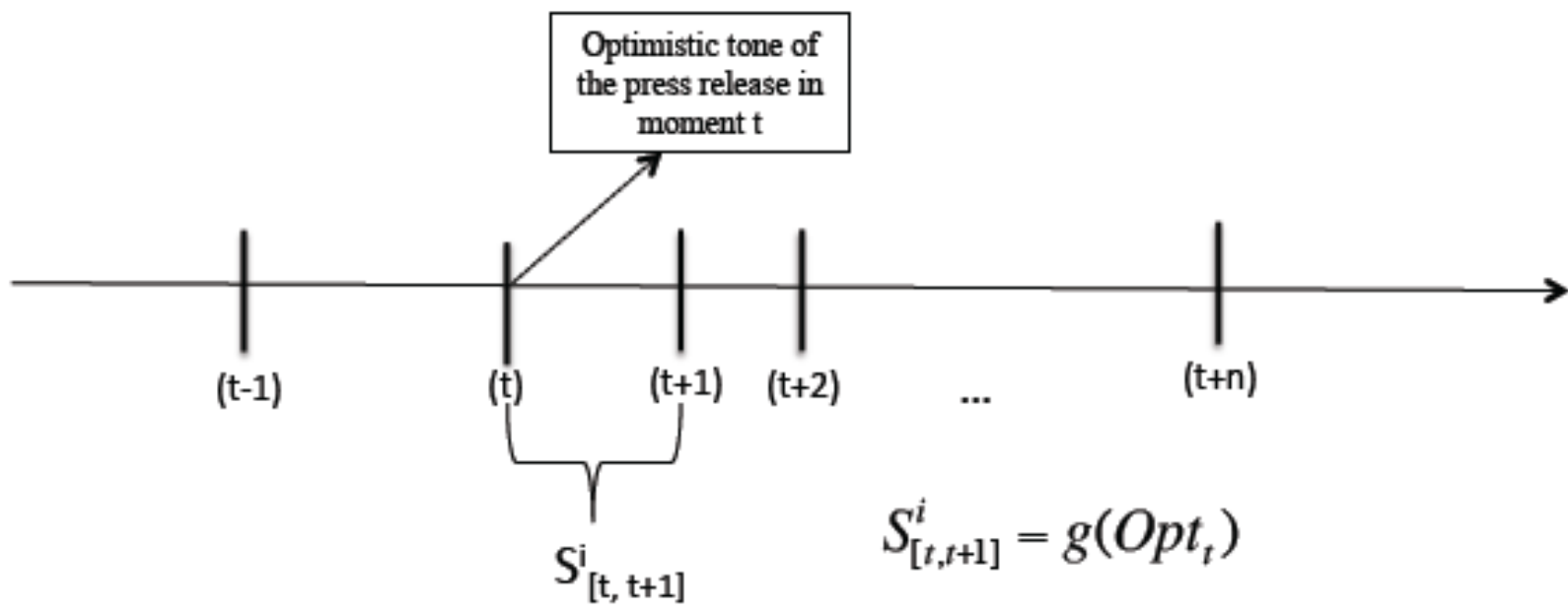

$\mathrm{t}=$ date of the press release

$\mathrm{t}-1=$ date of the immediately previous press release

$\mathrm{t}+1=$ date of the immediately following press release

$o p t_{t}=$ optimistic tone (positive words / total words) of the press release in date $\mathrm{t}$

$\mathrm{S}_{[\mathrm{t}-1, \mathrm{t}]}^{\mathrm{i}}=$ sentiment of audience $i$ during the period $[\mathrm{t}-1, \mathrm{t}]$

$\mathrm{S}_{[\mathrm{t}+1, \mathrm{t}]}=$ sentiment of audience $i$ during the period $[\mathrm{t}, \mathrm{t}+1]$

$i=$ Sole24Ore, Financial Times or analyst report 
Figure 2. Research findings
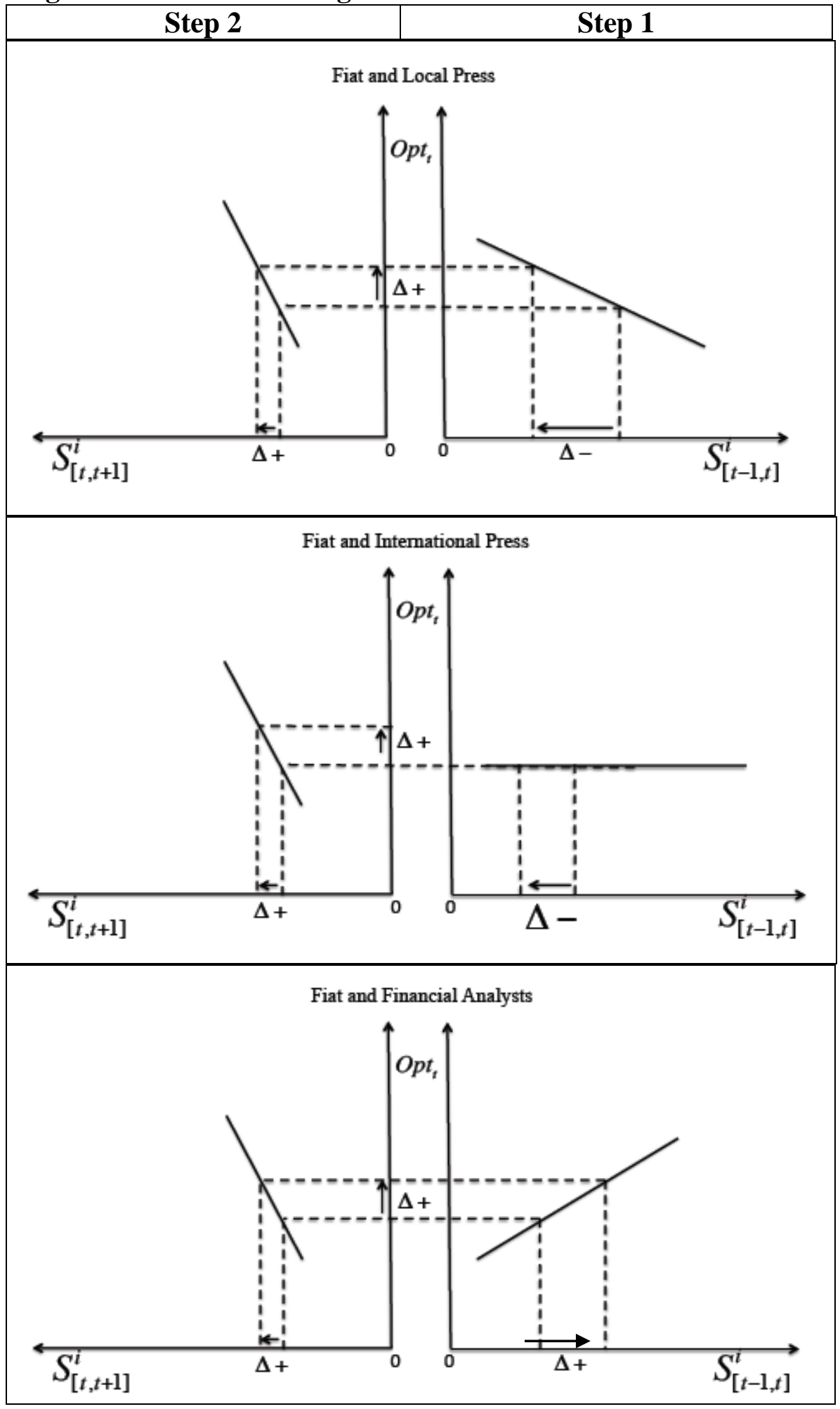

$\mathrm{t}=$ date of the press release

$\mathrm{t}-1=$ date of the immediately previous press release

$\mathrm{t}+1=$ date of the immediately following press release

$o p t_{t}=$ optimistic tone (positive words / total words) of the press release in date $\mathrm{t}$

$\mathrm{S}_{[\mathrm{t}-1, \mathrm{t}]}=$ sentiment of audience $i$ during the period $[\mathrm{t}-1, \mathrm{t}]$

$\mathrm{S}_{[\mathrm{t}+1, \mathrm{t}]}=$ sentiment of audience $i$ during the period $[\mathrm{t}, \mathrm{t}+1]$

$i=$ Sole24Ore, Financial Times or analyst report 
Table 1. Summary of variables employed in the study

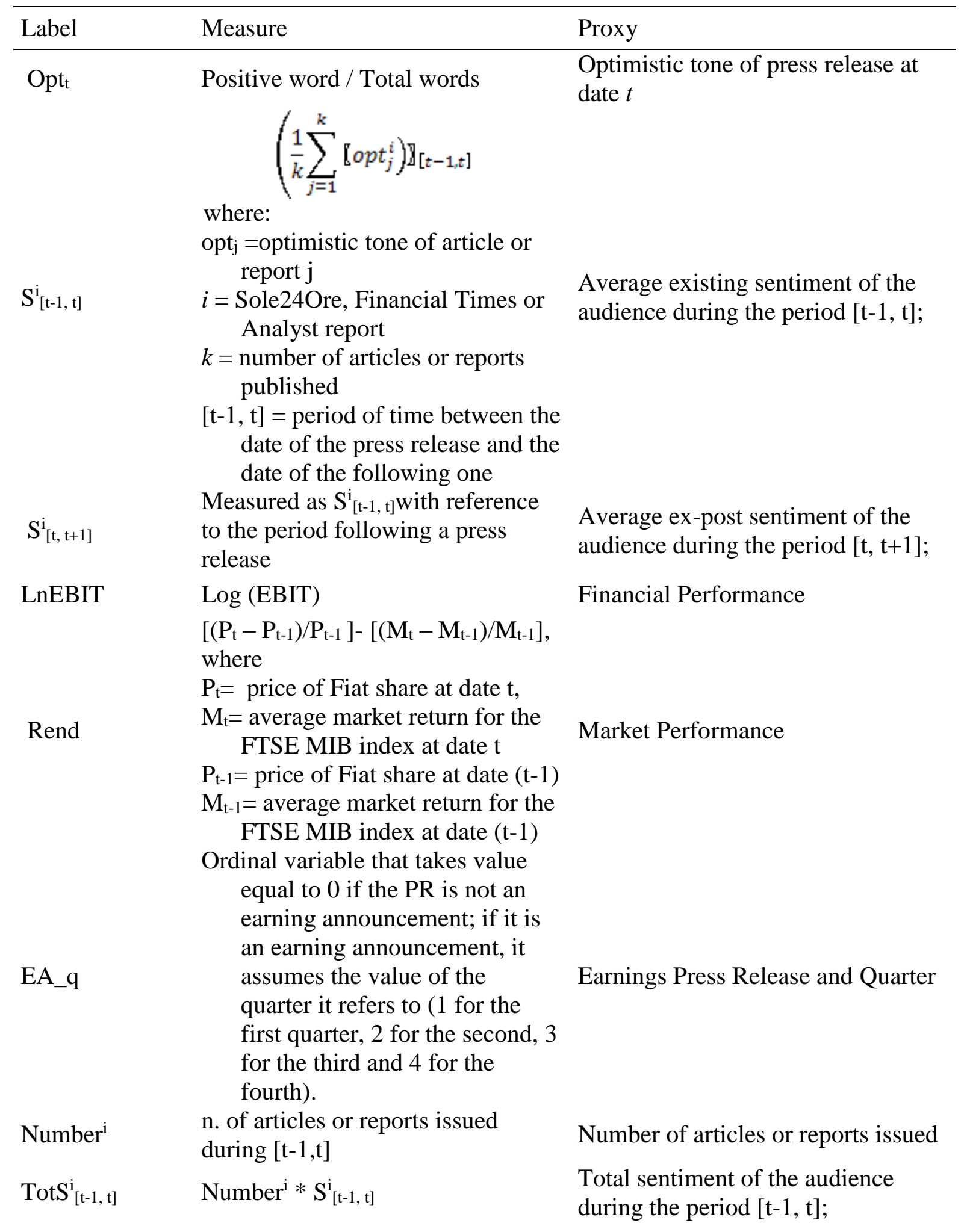


Table 2. Descriptive Statistics - Corporate disclosure tone

Panel A. Press releases

\begin{tabular}{|l|rrrrrrr|}
\hline \multicolumn{10}{|l|}{$\mathrm{N}=70$} \\
\hline Press releases & mean & $\mathrm{sd}$ & $\mathrm{min}$ & $\mathrm{p} 25$ & $\mathrm{p} 50$ & $\mathrm{p} 75$ & $\max$ \\
\hline Total Words & 2766.229 & 2900.620 & 230 & 558 & 1034.5 & 4615 & 9251 \\
Positive Words & 61.143 & 73.022 & 1 & 8 & 15 & 111 & 252 \\
Negative Words & 34.743 & 47.747 & 0 & 1 & 6 & 54 & 193 \\
& & & & & & & \\
Optimism & 0.019 & 0.007 & 0.003 & 0.014 & 0.018 & 0.023 & 0.034 \\
Pessimism & 0.009 & 0.008 & 0.000 & 0.002 & 0.008 & 0.013 & 0.041 \\
Net Optimism & $0.010^{\mathrm{a}}$ & 0.011 & -0.033 & 0.004 & 0.012 & 0.017 & 0.034 \\
\hline
\end{tabular}

Panel B. Press releases on Industrial relations

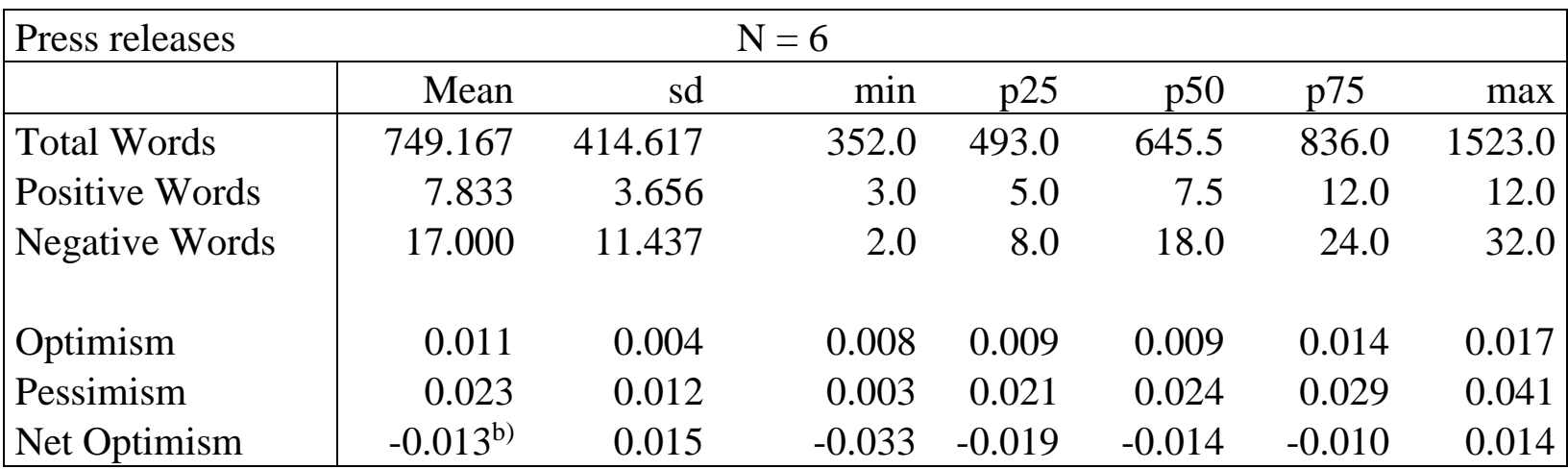

Panel C. Press releases on Results

\begin{tabular}{|l|rrrrrrr|}
\hline \multicolumn{10}{|l|}{ Press releases } & Mean & $\mathrm{sd}$ & $\mathrm{min}$ & $\mathrm{p} 25$ & $\mathrm{p} 50$ & $\mathrm{p} 75$ & $\max$ \\
\hline Total Words & 5063.848 & 2775.559 & 351 & 3275 & 5164 & 7754 & 9251 \\
Positive Words & 116.727 & 73.543 & 2 & 67 & 112 & 163 & 252 \\
Negative Words & 68.576 & 51.194 & 0 & 42 & 56 & 92 & 193 \\
& & & & & & & \\
Optimism & 0.022 & 0.007 & 0.004 & 0.017 & 0.023 & 0.026 & 0.032 \\
Pessimism & 0.012 & 0.006 & 0.000 & 0.009 & 0.011 & 0.017 & 0.027 \\
Net Optimism & $0.010^{\text {a) }}$ & 0.009 & -0.010 & 0.003 & 0.011 & 0.017 & 0.023 \\
\hline
\end{tabular}

Panel D. Press releases on Strategy

\begin{tabular}{|l|rrrrrrr|}
\hline \multicolumn{10}{|c|}{ Press releases } & Mean & $\mathrm{sd}$ & $\mathrm{min}$ & $\mathrm{p} 25$ & $\mathrm{p} 50$ & $\mathrm{p} 75$ & $\max$ \\
\hline Total Words & 710.774 & 344.839 & 230 & 428 & 648 & 951 & 1732 \\
Positive Words & 12.290 & 7.712 & 1 & 7 & 12 & 15 & 41 \\
Negative Words & 2.161 & 2.684 & 0 & 0 & 1 & 3 & 10 \\
& & & & & & & \\
Optimism & 0.017 & 0.006 & 0.003 & 0.013 & 0.017 & 0.020 & 0.034 \\
Pessimism & 0.004 & 0.004 & 0.000 & 0.000 & 0.002 & 0.006 & 0.014 \\
Net Optimism & $0.014^{\text {a) }}$ & 0.008 & -0.005 & 0.010 & 0.015 & 0.019 & 0.034 \\
\hline
\end{tabular}

a) Significantly different from zero at $\mathrm{p}<0.001$

b) Significantly different from zero at $p<0.100$ 
Table 3. Descriptive Statistics - Sentiment of audiences

Panel A. Articles and Analyst reports

\begin{tabular}{|l|rrrrrrr|}
\hline \multicolumn{1}{|l}{ Articles and analyst reports } & mean & $\mathrm{sd}$ & $\mathrm{min}$ & $\mathrm{p} 25$ & $\mathrm{p} 50$ & $\mathrm{p} 75$ & $\mathrm{Max}$ \\
\hline Total Words & 506.048 & 492.236 & 37 & 287 & 437 & 580 & 6571 \\
Positive Words & 11.788 & 17.370 & 0 & 4 & 7 & 13 & 245 \\
Negative Words & 8.162 & 12.496 & 0 & 2 & 5 & 9 & 144 \\
& & & & & & & \\
Optimism & 0.021 & 0.012 & 0.000 & 0.013 & 0.020 & 0.029 & 0.100 \\
Pessimism & 0.007 & 0.016 & 0.000 & 0.005 & 0.011 & 0.019 & 0.071 \\
Net Optimism & $0.014^{\text {a) }}$ & 0.011 & -0.051 & -0.004 & 0.009 & 0.018 & 0.091 \\
\hline
\end{tabular}

Panel B. Local press $-0.003$

\begin{tabular}{|l|rrrrrrr|}
\hline \multicolumn{10}{|l|}{ Sole24Ore } & Mean & $\mathrm{sd}$ & $\mathrm{min}$ & $\mathrm{p} 25$ & $\mathrm{p} 50$ & $\mathrm{p} 75$ & $\max$ \\
\hline & 398.872 & 186.521 & 47 & 231 & 391 & 538 & 2178 \\
Total Words & 7.618 & 5.565 & 0 & 3 & 6 & 11 & 42 \\
Positive Words & 5.192 & 4.840 & 0 & 1 & 4 & 8 & 32 \\
Negative Words & & & & & & & \\
& 0.020 & 0.012 & 0.000 & 0.011 & 0.019 & 0.026 & 0.100 \\
Optimism & 0.013 & 0.011 & 0.000 & 0.004 & 0.012 & 0.019 & 0.071 \\
Pessimism & $0.007^{\text {a) }}$ & 0.017 & -0.051 & -0.005 & 0.008 & 0.018 & 0.091 \\
Net Optimism & & & & & &
\end{tabular}

Panel C. International press

\begin{tabular}{|l|rrrrrrr|}
\hline \multicolumn{10}{|l|}{ Financial Times } & Mean & sd & min & p25 & p50 & p75 & $\max$ \\
\hline Total Words & 418.668 & 241.777 & 37 & 271 & 425 & 465 & 1891 \\
Positive Words & 8.000 & 5.864 & 0 & 4 & 6 & 11 & 43 \\
Negative Words & 5.420 & 4.530 & 0 & 3 & 4 & 7 & 31 \\
& & & & & & & \\
Optimism & 0.019 & 0.008 & 0.000 & 0.013 & 0.019 & 0.025 & 0.043 \\
Pessimism & 0.013 & 0.007 & 0 & 0.007 & 0.010 & 0.019 & 0.038 \\
Net Optimism & $0.006^{\text {a) }}$ & 0.011 & -0.026 & -0.002 & 0.009 & 0.014 & 0.031 \\
\hline
\end{tabular}

Panel D. Financial Analysts

\begin{tabular}{|l|rrrrrrr|}
\hline \multicolumn{1}{|l|}{ Analyst reports } & mean & sd & min & p25 & p50 & p75 & $\max$ \\
\hline Total Words & 1068.491 & 984.801 & 103 & 460 & 805 & 1229 & 6571 \\
Positive Words & 33.981 & 34.329 & 2 & 12 & 21 & 46 & 245 \\
Negative Words & 24.005 & 24.048 & 0 & 8 & 15 & 31 & 144 \\
& & & & & & & \\
Optimism & 0.030 & 0.011 & 0.006 & 0.023 & 0.029 & 0.036 & 0.087 \\
Pessimism & 0.022 & 0.011 & 0.000 & 0.014 & 0.020 & 0.028 & 0.079 \\
Net Optimism & $0.008^{\text {a) }}$ & 0.011 & -0.027 & 0.001 & 0.009 & 0.016 & 0.041 \\
\hline
\end{tabular}

${ }^{a}$ Significantly different from zero at $\mathrm{p}<0.001$ 
Table 4. Univariate Tests- Differences in means (row - columns; p value in parentheses)

\begin{tabular}{|c|c|c|c|c|}
\hline & $\begin{array}{l}\text { Sole24Ore } \\
\text { (c1) }\end{array}$ & $\begin{array}{c}\text { Financial Times } \\
(\mathrm{c} 2)\end{array}$ & $\begin{array}{l}\text { Analyst Reports } \\
\text { (c3) }\end{array}$ & \multirow{8}{*}{$\begin{array}{l}\tilde{n} \\
. \\
0 \\
0 \\
0\end{array}$} \\
\hline \multirow{2}{*}{ Sole24Ore (r1) } & & $(\mathrm{r} 1)-(\mathrm{c} 2)=0.001$ & $(\mathrm{r} 1)-(\mathrm{c} 3)=-0.010$ & \\
\hline & & $(0.0947)$ & $(0.0000)$ & \\
\hline \multirow{2}{*}{$\begin{array}{l}\text { Financial } \\
\text { Times (r2) }\end{array}$} & $(\mathrm{r} 2)-(\mathrm{c} 1)=-0.001$ & & $(\mathrm{r} 2)-(\mathrm{c} 3)=-0.011$ & \\
\hline & $(0.0674)$ & & $(0.0000)$ & \\
\hline \multirow{2}{*}{$\begin{array}{c}\text { Analyst } \\
\text { Reports (r3) }\end{array}$} & $(\mathrm{r} 3)-(\mathrm{c} 1)=0.001$ & $(\mathrm{r} 3)-(\mathrm{c} 2)=0.002$ & & \\
\hline & $(0.0578)$ & $(0.0071)$ & & \\
\hline \multicolumn{4}{|c|}{ Net Optimism } & \\
\hline
\end{tabular}

Lower: Net Optimism; Upper: Optimism 
Table 5. Univariate Tests - Correlation matrix

\section{4}

$1 \quad$ opt $_{\mathrm{t}}$

$2 \quad \mathrm{~S}^{\text {sole }}{ }_{[\mathrm{t}-1, \mathrm{t}]} \quad \begin{array}{ccc}-0.183 & 0.130 & 1\end{array}$

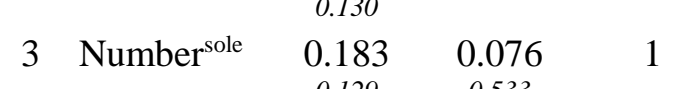

$\begin{array}{llcccc}4 & \mathrm{~S}^{\mathrm{FT}}{ }_{[\mathrm{t}-1, \mathrm{t}]} & \mathbf{0 . 2 7 8} & \mathbf{0 . 3 6 8} & 0.010 & 1\end{array}$

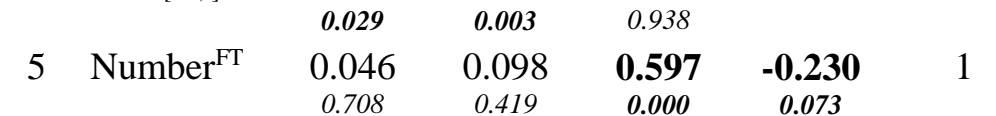

$\begin{array}{llllllll}6 & \mathrm{~S}^{\mathrm{FAR}}{ }_{[\mathrm{t}-1, \mathrm{t}]} & 0.084 & \mathbf{0 . 2 4 6} & 0.120 & \mathbf{0 . 3 6 5} & 0.065 & 1\end{array}$

$\begin{array}{llccccccc}7 & & 0.527 & \mathbf{0 . 0 6 0} & 0.367 & \mathbf{0 . 0 0 7} & 0.627 & & \\ & \text { Number }^{\mathrm{FAR}} & 0.022 & \mathbf{0 . 3 2 0} & \mathbf{0 . 5 1 5} & 0.060 & \mathbf{0 . 4 5 0} & \mathbf{0 . 3 6 7} & 1\end{array}$

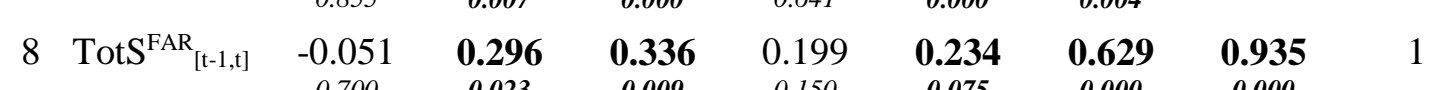

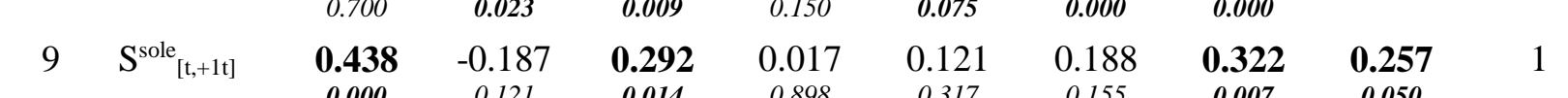

\begin{tabular}{|c|c|c|c|c|c|c|c|c|c|c|c|c|c|c|}
\hline 11 & $\mathrm{~S}^{\mathrm{FAR}}{ }_{[1, \mathrm{t}+1]}$ & $\begin{array}{c}0.267 \\
0.041\end{array}$ & $\begin{array}{c}0.095 \\
0.475\end{array}$ & $\begin{array}{c}0.219 \\
0.095\end{array}$ & $\begin{array}{c}0.173 \\
0.221\end{array}$ & $\begin{array}{c}0.104 \\
0.434\end{array}$ & $\begin{array}{c}0.393 \\
0.004\end{array}$ & $\begin{array}{c}0.187 \\
0.156\end{array}$ & $\begin{array}{c}0.297 \\
0.034\end{array}$ & $\begin{array}{c}0.265 \\
0.042\end{array}$ & $\begin{array}{c}0.510 \\
0.000\end{array}$ & 1 & & \\
\hline 12 & LnEbit & $\begin{array}{c}0.398 \\
0.001\end{array}$ & $\begin{array}{c}0.124 \\
0.307\end{array}$ & $\begin{array}{c}0.002 \\
0.989\end{array}$ & $\begin{array}{c}0.426 \\
0.001\end{array}$ & $\begin{array}{c}-0.143 \\
0.238\end{array}$ & $\begin{array}{c}0.154 \\
0.246\end{array}$ & $\begin{array}{c}-0.014 \\
0.906\end{array}$ & $\begin{array}{c}0.067 \\
0.615\end{array}$ & $\begin{array}{c}0.232 \\
0.054\end{array}$ & $\begin{array}{c}0.398 \\
0.001\end{array}$ & $\begin{array}{c}0.175 \\
0.184\end{array}$ & 1 & \\
\hline 13 & Rend & $\begin{array}{c}0.079 \\
0.513\end{array}$ & $\begin{array}{c}0.097 \\
0.427\end{array}$ & $\begin{array}{c}0.274 \\
0.022\end{array}$ & $\begin{array}{c}0.136 \\
0.291\end{array}$ & $\begin{array}{c}0.204 \\
0.091\end{array}$ & $\begin{array}{c}0.057 \\
0.667\end{array}$ & $\begin{array}{c}0.076 \\
0.533\end{array}$ & $\begin{array}{c}0.046 \\
0.730\end{array}$ & $\begin{array}{c}0.033 \\
0.784\end{array}$ & $\begin{array}{c}0.123 \\
0.340\end{array}$ & $\begin{array}{c}0.307 \\
0.018\end{array}$ & $\begin{array}{c}-0.002 \\
0.988\end{array}$ & 1 \\
\hline 14 & EAQ & $\begin{array}{c}0.396 \\
0.001\end{array}$ & $\begin{array}{c}-0.107 \\
0.377\end{array}$ & $\begin{array}{c}0.177 \\
0.143\end{array}$ & $\begin{array}{c}0.176 \\
0.171\end{array}$ & $\begin{array}{c}-0.024 \\
0.842\end{array}$ & $\begin{array}{c}0.041 \\
0.759\end{array}$ & $\begin{array}{c}0.094 \\
0.438\end{array}$ & $\begin{array}{c}-0.025 \\
0.853\end{array}$ & $\begin{array}{c}0.276 \\
0.021\end{array}$ & $\begin{array}{c}0.041 \\
0.750\end{array}$ & $\begin{array}{c}0.133 \\
0.315\end{array}$ & $\begin{array}{c}0.146 \\
0.229\end{array}$ & $\begin{array}{c}\mathbf{0 . 2 7 6} \\
0.021\end{array}$ \\
\hline
\end{tabular}

All variables are defined in Table 1

The matrix contains Pearson correlations and p-value. In bold the coefficient statistically significant at least at $5 \%$. 
Table 6. Relationship between optimism of audiences and ex-post optimism of press releases (Dependent Variable: Optimism)

\section{Ex-post Optimism of FIAT press releases $\left(\right.$ Opt $\left._{t}\right)$}

(1)

Sole24Ore
(2)

Financial Times
(3)

Analyst Reports

\begin{tabular}{|c|c|c|c|c|c|c|}
\hline $\mathbf{S}_{[\mathrm{it}-1, \mathrm{t}]}$ & $-0.450 *$ & & 0.135 & & $0.527 * *$ & \\
\hline & {$[0.053]$} & & {$[0.411]$} & & {$[0.047]$} & \\
\hline $\operatorname{Ln}\left(\mathbf{S}_{[\mathbf{i}-1, t]}\right)$ & & $-0.461 *$ & & 0.138 & & $0.540 * *$ \\
\hline & & {$[0.052]$} & & {$[0.410]$} & & {$[0.047]$} \\
\hline LnEBIT & $0.002 * * *$ & $0.002 * * *$ & $0.002 * *$ & $0.002 * *$ & $0.002 * *$ & $0.002 * *$ \\
\hline & [0.008] & [0.008] & [0.044] & [0.044] & [0.020] & [0.020] \\
\hline Rend & -0.001 & -0.001 & -0.002 & -0.002 & -0.000 & -0.000 \\
\hline & [0.859] & {$[0.860]$} & {$[0.790]$} & {$[0.790]$} & [0.975] & [0.974] \\
\hline EAQ & $0.002 * * *$ & $0.002 * * *$ & $0.002 * * *$ & $0.002 * * *$ & $0.002 * *$ & $0.002 * *$ \\
\hline & {$[0.008]$} & {$[0.008]$} & [0.002] & [0.002] & [0.025] & [0.025] \\
\hline Number ${ }^{\mathrm{i}}$ & 0.000 & 0.000 & 0.000 & 0.000 & $0.003 * *$ & $0.003 * *$ \\
\hline & {$[0.156]$} & [0.155] & [0.299] & [0.299] & [0.049] & [0.049] \\
\hline $\operatorname{Tot} S_{[t-1, t]}^{i}$ & & & & & $-0.088 * *$ & $-0.087 * *$ \\
\hline & & & & & [0.037] & [0.037] \\
\hline $\mathrm{LnOpt}_{\mathrm{t}-1}$ & 0.001 & 0.001 & -0.000 & -0.000 & -0.001 & -0.001 \\
\hline & [0.614] & [0.612] & [0.879] & [0.878] & [0.671] & {$[0.671]$} \\
\hline Constant & $0.023^{*}$ & $0.023 *$ & 0.007 & 0.007 & -0.007 & -0.007 \\
\hline & [0.065] & [0.064] & [0.609] & [0.613] & {$[0.620]$} & [0.615] \\
\hline Observations $^{\text {a) }}$ & 69 & 69 & 61 & 61 & 58 & 58 \\
\hline R-squared & 0.332 & 0.332 & 0.323 & 0.323 & 0.312 & 0.312 \\
\hline
\end{tabular}

p-value in brackets

$* * * \mathrm{p}<0.01, * * \mathrm{p}<0.05, * \mathrm{p}<0.1$

a) The number of observations in column (1) is 69 because we lose one observation when we control for the optimism of the press release in (t-1). The number of observations in column (2) is 61 because we only have 62 time periods during which we find articles on FIAT published by the Financial Times and we lose one observation when we control for the optimism of the press release in (t-1). The number of observations in column (3) is 58 because we only have 59 time periods during which there are analyst reports on FIAT and we lose one observation when we control for the optimism of the press release in $(\mathrm{t}-1)$.

All variables are defined in Table 1. 
Table 7. Relationship between optimism of press release and ex-post optimism of audiences

\begin{tabular}{|c|c|c|c|c|c|c|}
\hline & \multicolumn{6}{|c|}{ Ex-post optimism of audiences $\left(\mathrm{S}_{[\mathrm{t}, \mathrm{t}+1]}\right)$} \\
\hline & Sole? & 1) & Financi & ) & Analysts & $\begin{array}{l}\text { 3) } \\
\text { Reports }\end{array}$ \\
\hline Optt & $\begin{array}{c}0.169 * * \\
{[0.016]}\end{array}$ & & $\begin{array}{c}0.490 * * * \\
{[0.000]}\end{array}$ & & $\begin{array}{c}0.320 * * \\
{[0.010]}\end{array}$ & \\
\hline $\operatorname{Ln}\left(\mathbf{O p t} \mathbf{t}_{\mathbf{t}}\right.$ & & $\begin{array}{c}0.003 * * \\
{[0.018]}\end{array}$ & & $\begin{array}{c}0.007 * * * \\
{[0.000]}\end{array}$ & & $\begin{array}{c}0.005 * * \\
{[0.010]}\end{array}$ \\
\hline LnEBIT & $\begin{array}{c}0.000 \\
{[0.429]}\end{array}$ & $\begin{array}{c}0.000 \\
{[0.488]}\end{array}$ & $\begin{array}{c}0.001 \\
{[0.335]}\end{array}$ & $\begin{array}{c}0.000 \\
{[0.448]}\end{array}$ & $\begin{array}{c}0.000 \\
{[0.652]}\end{array}$ & $\begin{array}{c}0.000 \\
{[0.755]}\end{array}$ \\
\hline Rend & $\begin{array}{l}-0.000 \\
{[0.903]}\end{array}$ & $\begin{array}{l}-0.001 \\
{[0.832]}\end{array}$ & $\begin{array}{c}0.006 \\
{[0.295]}\end{array}$ & $\begin{array}{c}0.005 \\
{[0.397]}\end{array}$ & $\begin{array}{c}0.016 * * \\
{[0.011]}\end{array}$ & $\begin{array}{c}0.016 * * \\
{[0.015]}\end{array}$ \\
\hline EAQ & $\begin{array}{c}0.000 \\
{[0.333]}\end{array}$ & $\begin{array}{c}0.000 \\
{[0.308]}\end{array}$ & $\begin{array}{c}-0.001 * * \\
{[0.013]}\end{array}$ & $\begin{array}{c}-0.001 * * \\
{[0.025]}\end{array}$ & $\begin{array}{c}-0.001 \\
{[0.278]}\end{array}$ & $\begin{array}{c}-0.001 \\
{[0.279]}\end{array}$ \\
\hline $\operatorname{Ln} S_{[t-1, t]}^{i}$ & $\begin{array}{c}-0.127 \\
{[0.287]}\end{array}$ & $\begin{array}{c}-0.138 \\
{[0.246]}\end{array}$ & $\begin{array}{c}0.192 \\
{[0.103]}\end{array}$ & $\begin{array}{c}0.201 * \\
{[0.097]}\end{array}$ & $\begin{array}{c}0.360 * * * \\
{[0.003]}\end{array}$ & $\begin{array}{c}0.360 * * * \\
{[0.003]}\end{array}$ \\
\hline Constant & $\begin{array}{c}0.017 * * * \\
{[0.000]}\end{array}$ & $\begin{array}{c}0.031 * * * \\
{[0.000]}\end{array}$ & $\begin{array}{c}0.007 * * \\
{[0.011]}\end{array}$ & $\begin{array}{c}0.045 * * * \\
{[0.000]}\end{array}$ & $\begin{array}{c}0.013 * * * \\
{[0.003]}\end{array}$ & $\begin{array}{c}0.040 * * * \\
{[0.000]}\end{array}$ \\
\hline 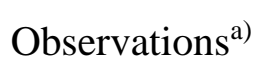 & 70 & 70 & 55 & 55 & 51 & 51 \\
\hline R-squared & 0.223 & 0.221 & 0.443 & 0.417 & 0.376 & 0.377 \\
\hline
\end{tabular}

p-value in brackets

$* * * \mathrm{p}<0.01, * * \mathrm{p}<0.05, * \mathrm{p}<0.1$

a) The number of observations in column (2) and column (3) is 55 and 51, respectively, because we lose 6 and 7 observations, respectively, when we control for the sentiment of each audience (international press and financial analysts) during the period $[\mathrm{t}-1, \mathrm{t}]$.

All variables are defined in Table 1 
Table 8. Three-stage least square model with simultaneous equations for the interactive relationship

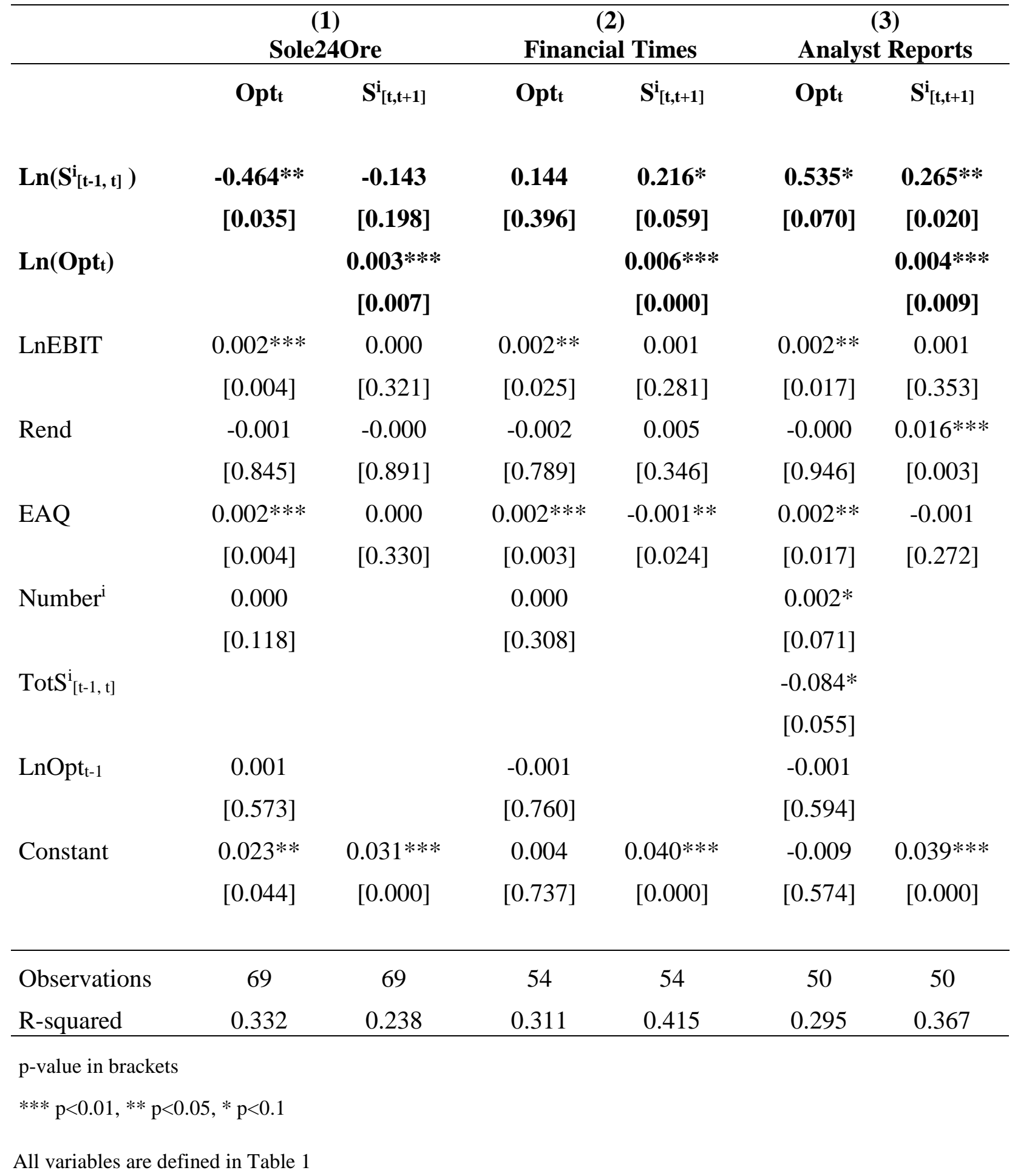


Table 9. Relationship between optimism of audiences and ex-post optimism of press releases

Robustness Check 1 - Dependent Variable: Net Optimism $=\left(\right.$ Opt $\left._{t}\right)-($ Pesst $)$

\section{Ex-post Net Optimism of FIAT press releases}

(1)

Sole240re
(2)

Financial Times
(3)

Analyst Reports

\begin{tabular}{|c|c|c|c|c|c|c|}
\hline \multirow[t]{2}{*}{$\mathbf{S}^{\mathbf{i}}[t-1, t]$} & \multicolumn{2}{|l|}{$-0.663 *$} & \multicolumn{2}{|l|}{0.136} & \multicolumn{2}{|l|}{$0.736 * *$} \\
\hline & {$[0.075]$} & & {$[0.564]$} & & [0.039] & \\
\hline \multirow[t]{2}{*}{$\operatorname{Ln}\left(\mathbf{S}_{[t-1, t]}\right)$} & & $-0.677 *$ & & 0.140 & & $0.756 * *$ \\
\hline & & {$[0.074]$} & & {$[0.561]$} & & [0.039] \\
\hline \multirow[t]{2}{*}{ LnEBIT } & $0.004 * * *$ & $0.004 * * *$ & $0.003 * * *$ & $0.003 * * *$ & $0.004 * * *$ & $0.004 * * *$ \\
\hline & {$[0.001]$} & {$[0.001]$} & {$[0.005]$} & {$[0.005]$} & {$[0.001]$} & {$[0.001]$} \\
\hline \multirow[t]{2}{*}{ Rend } & 0.001 & 0.001 & 0.000 & 0.000 & 0.000 & 0.000 \\
\hline & {$[0.930]$} & {$[0.930]$} & {$[0.976]$} & {$[0.978]$} & [0.986] & [0.987] \\
\hline \multirow[t]{2}{*}{ EAQ } & -0.001 & -0.001 & -0.001 & -0.001 & -0.001 & -0.001 \\
\hline & {$[0.354]$} & {$[0.354]$} & {$[0.514]$} & {$[0.513]$} & [0.307] & [0.307] \\
\hline \multirow[t]{2}{*}{ Number $^{\mathrm{i}}$} & $0.000 * *$ & $0.000 * *$ & 0.000 & 0.000 & 0.003 & 0.003 \\
\hline & {$[0.048]$} & {$[0.048]$} & {$[0.413]$} & {$[0.412]$} & [0.104] & [0.104] \\
\hline \multirow[t]{2}{*}{$\operatorname{Tot}^{\mathrm{i}}{ }_{[\mathrm{t}-1, \mathrm{t}]}$} & & & & & $-0.094 *$ & $-0.094 *$ \\
\hline & & & & & [0.093] & [0.093] \\
\hline \multirow[t]{2}{*}{$\operatorname{LnOpt}_{\mathrm{t}-1}{ }^{\mathrm{a})}$} & $0.006^{*}$ & $0.006^{*}$ & 0.004 & 0.004 & 0.004 & 0.004 \\
\hline & [0.079] & {$[0.079]$} & [0.209] & {$[0.211]$} & [0.244] & [0.244] \\
\hline \multirow[t]{2}{*}{ Constant } & 0.032 & 0.032 & 0.015 & 0.015 & -0.007 & -0.008 \\
\hline & [0.102] & {$[0.101]$} & {$[0.427]$} & {$[0.430]$} & [0.689] & {$[0.680]$} \\
\hline Observations & 69 & 69 & 61 & 61 & 58 & 58 \\
\hline R-squared & 0.350 & 0.351 & 0.337 & 0.337 & 0.415 & 0.415 \\
\hline
\end{tabular}

p-value in brackets

$* * * \mathrm{p}<0.01, * * \mathrm{p}<0.05, * \mathrm{p}<0.1$

(a) Results do not change if use the net optimism (instead of optimism) of the press release in period (t-1)

All variables are defined in Table 1 
Table 10. Relationship between optimism of press release and ex-post optimism of audiences

Robustness Check 1 - Dependent variable: net optimism (Positive Sentiment - Negative Sentiment)

\section{Ex-post net optimism of audiences}

(1)

Sole24Ore
(2)

Financial Times
(3)

Analysts Reports

\begin{tabular}{|c|c|c|c|c|c|c|}
\hline Optt & $\begin{array}{c}0.371 * * * \\
{[0.002]}\end{array}$ & & $\begin{array}{c}0.617 * * * \\
{[0.000]}\end{array}$ & & $\begin{array}{c}0.638 * * * \\
{[0.000]}\end{array}$ & \\
\hline $\operatorname{Ln}\left(\mathbf{O p t} \mathbf{t}_{\mathbf{t}}\right)$ & & $\begin{array}{c}0.006 * * * \\
{[0.003]}\end{array}$ & & $\begin{array}{c}0.009 * * * \\
{[0.000]}\end{array}$ & & $\begin{array}{c}0.008 * * * \\
{[0.001]}\end{array}$ \\
\hline LnEBIT & $\begin{array}{c}0.002 * * * \\
{[0.001]}\end{array}$ & $\begin{array}{c}0.002 * * * \\
{[0.002]}\end{array}$ & $\begin{array}{c}0.002 * * * \\
{[0.003]}\end{array}$ & $\begin{array}{c}0.002 * * * \\
{[0.007]}\end{array}$ & $\begin{array}{c}0.002 * * * \\
{[0.000]}\end{array}$ & $\begin{array}{c}0.003 * * * \\
{[0.001]}\end{array}$ \\
\hline Rend & $\begin{array}{c}0.006 \\
{[0.306]}\end{array}$ & $\begin{array}{c}0.006 \\
{[0.366]}\end{array}$ & $\begin{array}{c}0.005 \\
{[0.434]}\end{array}$ & $\begin{array}{c}0.004 \\
{[0.562]}\end{array}$ & $\begin{array}{c}0.008 \\
{[0.204]}\end{array}$ & $\begin{array}{c}0.007 \\
{[0.327]}\end{array}$ \\
\hline EAQ & $\begin{array}{c}-0.001 \\
{[0.104]}\end{array}$ & $\begin{array}{c}-0.001 \\
{[0.116]}\end{array}$ & $\begin{array}{c}-0.002 * * * \\
{[0.003]}\end{array}$ & $\begin{array}{c}-0.002 * * * \\
{[0.006]}\end{array}$ & $\begin{array}{c}-0.002 * * * \\
{[0.003]}\end{array}$ & $\begin{array}{c}-0.002 * * \\
{[0.021]}\end{array}$ \\
\hline $\operatorname{LnS}_{[t-1, t]}$ & $\begin{array}{c}-0.081 \\
{[0.693]}\end{array}$ & $\begin{array}{c}-0.104 \\
{[0.609]}\end{array}$ & $\begin{array}{c}0.243^{*} \\
{[0.090]}\end{array}$ & $\begin{array}{c}0.252 * \\
{[0.083]}\end{array}$ & $\begin{array}{c}0.181 \\
{[0.114]}\end{array}$ & $\begin{array}{c}0.181 \\
{[0.157]}\end{array}$ \\
\hline Constant & $\begin{array}{c}-0.004 \\
{[0.332]}\end{array}$ & $\begin{array}{c}0.027 * * * \\
{[0.003]}\end{array}$ & $\begin{array}{c}-0.013 * * * \\
{[0.000]}\end{array}$ & $\begin{array}{c}0.036^{* * *} * \\
{[0.001]}\end{array}$ & $\begin{array}{c}-0.015^{* * *} \\
{[0.001]}\end{array}$ & $\begin{array}{c}0.028 * * * \\
{[0.010]}\end{array}$ \\
\hline Observations & 70 & 70 & 55 & 55 & 51 & 51 \\
\hline R-squared & 0.373 & 0.370 & 0.576 & 0.564 & 0.590 & 0.488 \\
\hline
\end{tabular}

p-value in brackets

$* * * \mathrm{p}<0.01, * * \mathrm{p}<0.05, * \mathrm{p}<0.1$

All variables are defined in Table 1 
Table 11. Relationship between optimism of audiences and ex-post optimism of press releases

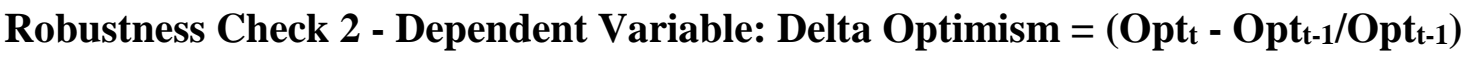

\begin{tabular}{|c|c|c|c|c|c|c|}
\hline & \multicolumn{6}{|c|}{ Variation in Optimism of FIAT press releases } \\
\hline & Sole2 & $\begin{array}{l}\text { 4) } \\
\text { 4Ore }\end{array}$ & $\begin{array}{r}(2 \\
\text { Financia } \\
\end{array}$ & I Times & Analys & $\begin{array}{l}\text { Reports } \\
\text { Res }\end{array}$ \\
\hline $\mathbf{S}_{[\mathrm{i}-1, \mathrm{t}]}$ & $\begin{array}{c}\mathbf{8 1 . 3 6 0} * * * \\
{[0.000]}\end{array}$ & & $\begin{array}{l}-20.710 \\
{[0.323]}\end{array}$ & & $\begin{array}{c}8.310 \\
{[0.762]}\end{array}$ & \\
\hline $\operatorname{Ln}\left(\mathbf{S}_{[\mathbf{i}-1, \mathrm{t}]}\right)$ & & $\begin{array}{c}\mathbf{8 2 . 9 7 2} * * * \\
{[0.000]}\end{array}$ & & $\begin{array}{l}-21.275 \\
{[0.320]}\end{array}$ & & $\begin{array}{c}8.551 \\
{[0.761]}\end{array}$ \\
\hline LnEBIT & $\begin{array}{c}-0.049 \\
{[0.395]}\end{array}$ & $\begin{array}{c}-0.049 \\
{[0.397]}\end{array}$ & $\begin{array}{c}-0.064 \\
{[0.297]}\end{array}$ & $\begin{array}{c}-0.063 \\
{[0.298]}\end{array}$ & $\begin{array}{c}-0.066 \\
{[0.384]}\end{array}$ & $\begin{array}{c}-0.066 \\
{[0.384]}\end{array}$ \\
\hline Rend & $\begin{array}{c}0.002 \\
{[0.997]}\end{array}$ & $\begin{array}{c}0.002 \\
{[0.997]}\end{array}$ & $\begin{array}{c}0.301 \\
{[0.635]}\end{array}$ & $\begin{array}{c}0.302 \\
{[0.633]}\end{array}$ & $\begin{array}{c}-0.061 \\
{[0.935]}\end{array}$ & $\begin{array}{c}-0.061 \\
{[0.934]}\end{array}$ \\
\hline EAQ & $\begin{array}{c}0.140 * * \\
{[0.018]}\end{array}$ & $\begin{array}{c}0.140 * * \\
{[0.018]}\end{array}$ & $\begin{array}{c}0.208 * * * \\
{[0.001]}\end{array}$ & $\begin{array}{c}0.208 * * * \\
{[0.001]}\end{array}$ & $\begin{array}{c}0.182 * * * \\
{[0.010]}\end{array}$ & $\begin{array}{c}0.182 * * * \\
{[0.010]}\end{array}$ \\
\hline Number ${ }^{\mathrm{i}}$ & $\begin{array}{c}0.005 \\
{[0.258]}\end{array}$ & $\begin{array}{c}0.005 \\
{[0.256]}\end{array}$ & $\begin{array}{c}-0.002 \\
{[0.951]}\end{array}$ & $\begin{array}{l}-0.002 \\
{[0.953]}\end{array}$ & $\begin{array}{c}0.055 \\
{[0.678]}\end{array}$ & $\begin{array}{c}0.055 \\
{[0.677]}\end{array}$ \\
\hline $\operatorname{TotS}_{[t-1, t]} i$ & & & & & $\begin{array}{c}-3.478 \\
{[0.430]}\end{array}$ & $\begin{array}{c}-3.477 \\
{[0.428]}\end{array}$ \\
\hline Constant & $\begin{array}{c}1.610 * * * \\
{[0.000]}\end{array}$ & $\begin{array}{c}1.624 * * * \\
{[0.000]}\end{array}$ & $\begin{array}{c}0.544 \\
{[0.250]}\end{array}$ & $\begin{array}{c}0.551 \\
{[0.249]}\end{array}$ & $\begin{array}{c}0.255 \\
{[0.744]}\end{array}$ & $\begin{array}{c}0.252 \\
{[0.750]}\end{array}$ \\
\hline Observations & 69 & 69 & 61 & 61 & 58 & 58 \\
\hline R-squared & 0.315 & 0.315 & 0.309 & 0.309 & 0.221 & 0.221 \\
\hline
\end{tabular}

p-value in brackets

$* * * \mathrm{p}<0.01, * * \mathrm{p}<0.05, * \mathrm{p}<0.1$

All variables are defined in Table 1 
Table 12. Relationship between optimism of press release and ex-post optimism of audiences

Robustness Check 2 - Dependent variable: Delta optimism( $\left(\mathbf{S}_{[t, t+1]}-S_{[t-1, t]}^{i_{i}} / S_{[t-1, t]}\right)$

Variation of optimism of audiences

(1)

Sole24Ore
(2)

Financial Times
(3)

Analysts Reports

\begin{tabular}{|c|c|c|c|c|c|c|}
\hline Opt $t_{t}$ & $\begin{array}{c}23.818 * * * \\
{[0.000]}\end{array}$ & & $\begin{array}{c}24.900 * * * \\
{[0.009]}\end{array}$ & & $\begin{array}{l}12.297 * \\
{[0.070]}\end{array}$ & \\
\hline $\operatorname{Ln}\left(\mathbf{O p t} \mathbf{t}_{\mathrm{t}}\right)$ & & $\begin{array}{c}0.351 * * * \\
{[0.001]}\end{array}$ & & $\begin{array}{c}0.410 * * * \\
{[0.005]}\end{array}$ & & $\begin{array}{c}0.174 \\
{[0.106]}\end{array}$ \\
\hline LnEBIT & $\begin{array}{l}-0.055^{*} \\
{[0.092]}\end{array}$ & $\begin{array}{c}-0.057 * \\
{[0.093]}\end{array}$ & $\begin{array}{l}-0.088 * \\
{[0.056]}\end{array}$ & $\begin{array}{c}-0.099 * * \\
{[0.035]}\end{array}$ & $\begin{array}{c}-0.022 \\
{[0.553]}\end{array}$ & $\begin{array}{c}-0.022 \\
{[0.549]}\end{array}$ \\
\hline Rend & $\begin{array}{c}-0.350 \\
{[0.309]}\end{array}$ & $\begin{array}{c}-0.402 \\
{[0.251]}\end{array}$ & $\begin{array}{c}-0.245 \\
{[0.584]}\end{array}$ & $\begin{array}{c}-0.302 \\
{[0.497]}\end{array}$ & $\begin{array}{c}0.462 \\
{[0.178]}\end{array}$ & $\begin{array}{c}0.440 \\
{[0.203]}\end{array}$ \\
\hline EAQ & $\begin{array}{c}0.008 \\
{[0.814]}\end{array}$ & $\begin{array}{c}0.013 \\
{[0.690]}\end{array}$ & $\begin{array}{c}-0.070 \\
{[0.129]}\end{array}$ & $\begin{array}{c}-0.068 \\
{[0.127]}\end{array}$ & $\begin{array}{c}-0.034 \\
{[0.327]}\end{array}$ & $\begin{array}{c}-0.031 \\
{[0.369]}\end{array}$ \\
\hline Constant & $\begin{array}{l}-0.228^{*} \\
{[0.065]}\end{array}$ & $\begin{array}{c}1.645 * * * \\
{[0.001]}\end{array}$ & $\begin{array}{l}-0.049 \\
{[0.777]}\end{array}$ & $\begin{array}{c}2.118 * * * \\
{[0.002]}\end{array}$ & $\begin{array}{c}-0.103 \\
{[0.451]}\end{array}$ & $\begin{array}{l}0.836 * \\
{[0.098]}\end{array}$ \\
\hline $\begin{array}{l}\text { Observations } \\
\text { R-squared }\end{array}$ & $\begin{array}{c}70 \\
0.213\end{array}$ & $\begin{array}{c}70 \\
0.187\end{array}$ & $\begin{array}{c}55 \\
0.158\end{array}$ & $\begin{array}{c}55 \\
0.175\end{array}$ & $\begin{array}{c}51 \\
0.102\end{array}$ & $\begin{array}{c}51 \\
0.089\end{array}$ \\
\hline
\end{tabular}

p-value in brackets

$* * * \mathrm{p}<0.01, * * \mathrm{p}<0.05, * \mathrm{p}<0.1$

All variables are defined in Table 1 


\section{Appendix 1 - Examples of coding}

\section{Extract from Press Release "FIAT AND GM REACH SETTLEMENT AGREEMENT",}

February 13, 2005"

\section{Total words: 555}

Count of Positive words: 29

Count of Negative words: 5

Net optimism: 0.043

The Boards of Directors of Fiat and General Motors have met today to approve a contract to terminate the Master Agreement and related Joint Ventures between the two companies.

The Chairman of Fiat, Luca Cordero di Montezemolo said "We are delighted to have been able to conclude this agreement with General Motors. While highly beneficial to both Fiat and GM since 2000, the arrangements had become too confining for the development of Fiat Auto in today's market environment. We now have all the necessary freedom to develop strategic growth alternatives for Fiat Auto, while retaining a base on which to build a much more constructive relationship with GM in the future.

"I believe that the successful outcome of the negotiations will create an important stimulus for Fiat Auto's workforce to achieve the ambitious objectives that they have set themselves. It is also a most positive response for our customers, for whom we will be introducing four completely new models (two Fiat and two Alfa Romeo) in 2005.

The Chief executive Officer of Fiat S.p.A, Sergio Marchionne said: "I firmly believe that the settlement reached with GM is fair and equitable to both parties. While on the one hand it deals with the valorization of the put option contained in the Master Agreement, it grants Fiat all the necessary freedom to develop its Auto business. We can now clearly focus on the operational objectives of Fiat Auto, and devote our full energies to the re-establishment and rationalization of our brands and the building of an effective network to maximize the success of our new product portfolio. The benefits of the relationship with GM are being preserved through a long term supply arrangement and other cooperation agreements, such as participation by Fiat in the GM alliance purchasing team model."

\section{Press Release "Truck drivers strike", December 11, 2007}

Total words: 157

Count of Positive words: 4

Count of Negative words: 12

Net optimism: -0.051

The strike of truck drivers is creating serious difficulties to the manufacturing system of the Fiat Group in Italy. The protest began yesterday and blocked the regular flow of materials and components from suppliers to all Groups plants.

The lack of supplies in many plants caused the suspension of activities. As of this afternoon, more than 22,000 Group employees were temporarily laid off and their number is expected to grow in the next few days and involve all the 50,000 workers of the manufacturing areas.

The fact that one single labour dispute has such a far-reaching effect on the production system and on the Italian economy contributes to drastically reducing the competitiveness of our country. In the general interest we hope that conduct rules will soon be defined, in order to limit the impact of disputes without jeopardizing anybody's rights.

We also hope that parties are available to start negotiations that may lead in a positive outcome. 